\title{
THE IMPACT OF A DROP PROGRAM ON THE AGE OF RETIREMENT AND EMPLOYER PENSION COSTS
}

\author{
Samson Alva, Norma B. Coe, and Anthony Webb
}

CRR WP 2010-11

Date Released: September 2010

Date Submitted: August 2010

\section{Center for Retirement Research at Boston College \\ Hovey House \\ 140 Commonwealth Avenue \\ Chestnut Hill, MA 02467}

Tel: 617-552-1762 Fax: 617-552-0191

Samson Alva is a research assistant in economics at Boston College. Norma B. Coe is assistant director of research at the Center for Retirement Research at Boston College (CRR). Anthony Webb is a research economist at the CRR. The research reported herein was pursuant to funding from the City of Philadelphia. The findings and conclusions expressed are solely those of the authors and do not represent the views of the City of Philadelphia or Boston College.

(C) 2010, by Samson Alva, Norma B. Coe, and Anthony Webb. All rights reserved. Short sections of text, not to exceed two paragraphs, may be quoted without explicit permission provided that full credit, including (C) notice, is given to the source. 


\title{
About the Center for Retirement Research
}

The Center for Retirement Research at Boston College, part of a consortium that includes parallel centers at the University of Michigan and the National Bureau of Economic Research, was established in 1998 through a grant from the Social Security Administration. The Center's mission is to produce first-class research and forge a strong link between the academic community and decision makers in the public and private sectors around an issue of critical importance to the nation's future. To achieve this mission, the Center sponsors a wide variety of research projects, transmits new findings to a broad audience, trains new scholars, and broadens access to valuable data sources.

\section{Center for Retirement Research at Boston College}

\author{
Hovey House \\ 140 Commonwealth Avenue \\ Chestnut Hill, MA 02467 \\ phone: 617-552-1762 fax: 617-552-0191 \\ e-mail: crr@bc.edu \\ crr.bc.edu
}

Affiliated Institutions:

The Brookings Institution

Massachusetts Institute of Technology

Syracuse University

Urban Institute 


\begin{abstract}
This paper investigates the impact of a Deferred Retirement Option Plan (DROP) on the age of retirement of employees covered by defined benefit pension plans provided by the City of Philadelphia. We show that the program results in significant and substantial increases in the age of retirement: 1.25 years on average for municipal employees. Employees make use of the program in ways that maximize the expected present value of their pension benefits, with municipal employees entering the program an average 2.1 years before the age at which they would otherwise have retired. Consequently, the program results in a substantial increase in pension cost. We estimate that the program has cost the city around $\$ 258$ million over the period to 31 December 2009. We construct an indicator of employee quality and find that some classes of high-quality employees are disproportionately likely to delay retirement as a result of the program.
\end{abstract}




\section{Introduction}

Previous research has shown that defined benefit pension plans typically incorporate incentives that encourage early retirement. For example, Friedberg and Webb (2005) estimate that, on average, employees in defined benefit plans retire about two years earlier than otherwise similar employees in defined contribution plans. These age-related incentives may disadvantage those workers who would otherwise prefer to retire later. Although defined benefit pension plans may benefit the employer by ensuring that workers retire at particular ages and by providing a predictable retirement pattern, they may also impose costs on the employer if they result in the premature loss of productive and knowledgeable employees.

Some employers have responded to these issues by introducing programs that reduce the pension disincentives to continued employment by older workers. ${ }^{1}$ One such program is a Deferred Retirement Option Plan (DROP). In a typical DROP program, employees are able to freeze pension benefits while continuing to work for the employer for a specified maximum period without accruing additional benefits. ${ }^{2}$ During this period, the pension benefits are credited to a notional interest-bearing account, the balance on which is paid to the employee upon eventual retirement.

It is unclear what effect programs of this type have on the average age of retirement or on the cost to the employer of providing pensions. On one hand, they might have little effect on the age of retirement, with employees choosing to spend their last few years of service under the special program. Given that a well-informed employee would elect to enter the DROP program only if participation were to his financial advantage, there is a risk that the program could increase the employer's pension costs. On the other hand, it is possible that an employee might enter the program at the age at which he would otherwise have retired and remain on the job. The program would then increase the age of final retirement and be cost-neutral to the employer, provided the interest rate paid on

\footnotetext{
${ }^{1}$ The authors have identified a total of 33 public sector pension plans offering DROP-type programs.

2 The principal features of DROP programs are described in Steffen (2001).
} 
the account equals the interest rate that the employer can earn on the deferred pension benefits.

Besides the cost of the program, the employer may also be concerned about the types of employees who choose to delay retirement. If the employer operates age-related salary scales, the employees who delay retirement may earn higher salaries than their putative replacements. The cost or benefit to the employer might also depend on whether the employees who were induced to retire were of higher or lower quality than average, or possessed skills that were unusually difficult to replace.

Using data supplied by the City of Philadelphia, covering periods both prior and subsequent to the introduction of a delayed retirement program, we investigate the impact of the program on the age of retirement and the program's cost to the employer. We find that on average, municipal workers delay retirement by more than 1.25 years. The effect for firefighters and police officers is much smaller, between two months to one year. The program imposes significant costs on the employer. Although the magnitude of these costs is somewhat sensitive to the assumptions made regarding real wage growth, interest, and inflation rates, there are no plausible combinations of these parameters at which the program is cost-neutral to the pension plan. Data limitations constrain our ability to identify high-quality employees. We find evidence that high-quality fire department employees, identified from an analysis of salary increases, are disproportionately likely to delay retirement as a result of the program. But we find the opposite relationship for police department employees, and these findings must be regarded as tentative. A full accounting of the costs and benefits of the program would also need to incorporate an estimate of the extent to which these employees were more productive than average.

The remainder of this paper is organized as follows. Section one describes the program, and reviews the limited literature on programs of this type. Section two describes the data. Section three explains our econometric methodology. Section four presents our results, and Section five concludes. 


\section{The Deferred Retirement Program}

The City of Philadelphia operates a defined benefit pension plan for members of the city police and fire departments, municipal employees, and elected officials. The retirement plan parameters are outlined in Table 1. Police and fire employees hired after July 1, 1988, are entitled to retire at age 50 after having completed 10 years of service. The benefit accrual rate is 2.2 percent of the highest two years of pensionable earnings for the first 20 years, and 2 percent thereafter. These employees can retire at age 40 with 10 years of service, subject to a benefit reduction of 0.5 percent for each month the employee is younger than 50. Municipal employees are entitled to full benefits at age 60, based on the highest three years of earnings. Their accrual rate is 2.2 percent for 10 years, and 2 percent thereafter. They can retire at age 52 with 10 years of service, again subject to a 0.5 percent per month benefit reduction. ${ }^{3}$ Neither class of employee can receive benefits that exceed 100 percent of pensionable earnings. Benefits for both classes of employees vest after 10 years, and after five years for some classes of individuals hired after January 13, 1999. ${ }^{4}$ Vested employees receive a separation service benefit, a deferred pension based on years of service and payable at the age they would otherwise have been entitled to full or reduced benefits. Married employees can elect to receive a smaller pension plus a survivor benefit, with the reduction being approximately actuarially fair on average.

The above rules incorporate strong age-related incentives that discourage retirement at some ages and encourage it at others. Previous research - for example, Coile and Gruber (2000), Coile (2004), and Friedberg and Webb (2005) - show that age-related pension incentives have a powerful impact on retirement behavior. These incentives are most frequently measured by comparing the pension wealth if one retires this year with the pension wealth if one retires in some future year. The pension wealth of an employee at time $t$ equals:

\footnotetext{
${ }^{3}$ Elected officials are entitled to retire at age 55 after 10 years of service, and have an accrual rate of 3.5\%.

${ }^{4}$ Individuals who are both exempt from Civil Service and not entitled to be represented by a union.
} 


$$
P_{t}^{D B}=E_{t}\left[\sum_{s=t}^{T} \frac{1}{(1+r)^{s-t}} \delta_{s \mid t} p(q, t)\right]
$$

where $P_{t}^{D B}$ is the expected present value of pension benefits at time $t, r$ is the interest rate, $\delta_{s \mid t}$ is the conditional probability of surviving to time $s$, and $p(q, t)$ is the annual pension payable at a commencement date of $q, q>t$. The expected accrual rate of pension wealth is simply $E_{t}\left(P_{t+1}^{D B}\right)-P_{t}^{D B}$. The rate of accrual of pension wealth will be zero until vesting, when it will spike. The rate of accrual will generally increase as the employee approaches the age at which he is eligible for benefits.

When choosing his retirement age, an employee will take into account not only the oneperiod accrual rate, but also the whole pattern of expected future accruals. He may be willing to work for a low current-period accrual, in anticipation of larger future accruals. But at some age, the accrual rate will turn negative because the increase in the annual benefit will no longer be sufficient to compensate for the loss of one year's pension income. At that point, the employee faces a strong financial incentive to retire.

Figure 1 shows pension wealth by age, discounted to age 50, for stylized male police/fire and municipal employees, expressed in constant 2009 dollars, in the three scenarios of early retirement, normal retirement, and optimal use of the DROP program. ${ }^{5}$ DROPeligible fire, police, and municipal employees commenced employment at average ages of 26, 28, and 36, respectively. To illustrate the effects of pension plan type on pension wealth accrual, we assume that all three types of employees commence employment in the year 2000 at age $30 .^{6}$

\footnotetext{
${ }^{5}$ We discount back to age 50 to distinguish between the effects on pension wealth of additional years of service and the passage of time. Were we to discount back to a different age, the shape of pension wealth accruals would be preserved, but the present values would change.

${ }^{6}$ For comparison, Appendix Figures $1 \mathrm{~A}$ and $1 \mathrm{~B}$ show pension wealth accrual for fire, police, and municipal employees who commenced employment prior to 1988. Appendix Figure 1A assumes a commencement age of 30 for all three classes, and Appendix Figure 1B assumes ages of 26, 28, and 36, respectively. Our objective is to illustrate solely the effect of differences in pension plan rules. We therefore assume that the employees illustrated in Figures 1A and 1B have the same starting salary and the same annual mortality risk as those in Figure 1. For the same reason, we discount the present values back to the same ages, but different years.
} 
The employees are born in 1970, and commence employment in 2000 at a salary (in 2009 dollars) of $\$ 40,000$ a year. Their nominal salaries grow by the sum of 2.5 percent annual inflation and 1.1 percent real wage growth. ${ }^{7}$ Pension wealth is calculated using population mortality tables for the relevant birth cohort and an assumed 3 percent discount rate. ${ }^{8}$ For both types of employees, pension wealth is zero until vesting at age 40. Pension wealth increases as the normal retirement age approaches. In each case, the expected present value of pension wealth of an employee who retires early differs only slightly from that of someone who chooses to wait until his normal retirement age before receiving benefits, due to the actuarial fairness of the early retirement system. For our stylized municipal employee, pension wealth peaks at the age he is entitled to unreduced benefits. ${ }^{9}$ From that age on, the expected present value of benefits declines at an accelerating rate.

But this is not true of our stylized police/fire employee. He is entitled to a benefit of 44 percent of pensionable earnings at the age he is entitled to unreduced pension benefits. If he serves another year, his pension benefit increases to 46 percent of a salary that is 3.6 percent higher in nominal terms, so that his pension increases by 8.3 percent in nominal terms, or 5.7 percent in real terms. Although this larger pension starts one year later, the inflation-adjusted expected present value of the pension payable at age 51, adjusting for the one-year mortality rate, exceeds the expected present value of the pension payable at age 50. The police/fire employee maximizes the expected present value of his pension benefits at age 54, a full four years after he is entitled to full benefits. Delaying retirement from age 50 to 54 increases the age-50 expected present value of pension

\footnotetext{
${ }^{7}$ The Social Security Administration Trustees Report assumes 1.1 percent economy-wide wage growth. Individual employees may anticipate more rapid wage growth if they are paid by reference to age-related salary scales or anticipate promotion.

${ }^{8}$ There are substantial socioeconomic differences in mortality rates. We find that our results are insensitive to alternative plausible assumptions regarding mortality.

${ }^{9}$ At a lower discount or inflation rate or a higher assumed rate of wage growth, pension wealth would be greater and would peak at older ages.
} 
benefits by 2.13 percent, although the rate of accrual from age 50 to 54 is much lower than that enjoyed prior to age $50 .{ }^{10}$

Prior to the DROP program, employees had to retire in order to collect benefits. Each period, employees would decide whether to work or retire. They would weigh the utility of retiring against working another year and deciding in the next period whether to retire. The value of the decision, $V_{t}=V_{t}\left(R_{t}\right)$ where $R_{t}$ equals one if the decision is to retire, zero otherwise. Suppose that the value of staying in the job this period is

$V_{t}(0)=U^{0}\left(W_{t}\right)+B E\left(V_{t+1}\right)$

the sum of the utility from the wage $W_{t}$ received this period and the discounted value of facing the retirement decision next period, where $B$ is the discount factor. Suppose the value of retiring is

$V_{t}(1)=U^{1}\left(P_{t}\right)$

which depends on pension wealth, $P_{t}$, and possibly other factors, such as utility from leisure or another job. The outcome depends on how current and expected future compensation in the job compare to the value of retirement.

The DROP program expands the choices available to the employee. Any employee who has reached his plan's normal retirement age and who has at least 10 years of service can elect to join the program. Upon entry, which is irrevocable, the employee ceases to pay pension contributions or accrue benefits. The employee may continue to work for the city for a maximum of four years. During that time, his monthly pension benefit is credited to a tax-deferred, interest-bearing account. The Board of Pensions and Retirement determines the interest rate, subject to a minimum of 4.5 percent, the rate

\footnotetext{
${ }^{10}$ For all classes of employees, at a younger assumed commencement age, pension wealth would be greater at any given age, and would peak at a younger age.
} 
payable since the inception of the program. On eventual retirement, the balance in the account is paid to the employee as a lump sum.

Employees now face a nested decision: whether to join the DROP program and, conditional on joining, whether to work or claim benefits. Suppose that the value of staying in the job this period is

$V_{t}^{D R O P}(0)=U^{0}\left(W_{t}\right)+\mathrm{BE}\left(V_{t+1}^{D R O P}\right)$

the sum of the utility from the wage $W_{t}$ received this period and the discounted value of facing the option to retire and claim accumulated pension and possibly DROP benefits the following period. The employee can retire without making use of the DROP program, in which case,

$V_{t}^{D R O P}(1)=U^{1}\left(P_{t}\right)$

or the employee can elect to enter the DROP program. If the employee enters the program, he receives utility from the wage payable this period and the discounted value of facing the option to retire and claim his DROP pension benefits and lump sum or, subject to the four-year rule, continuing to work:

$V_{t}^{D R O P}(2)=U^{0}\left(W_{t}\right)+B E\left(V_{t+1}^{* D R O P}\right)$

where $V_{t+1}^{* D R O P}$ is the value of the participant's decision to either work or claim DROP benefits.

Referring back to Figure 1, at our assumed discount rate, municipal employees would find it optimal to participate in the DROP program only at desired retirement ages greater 
than 60, and fire and police employees at desired retirement ages greater than $54{ }^{11}$ The DROP program reduces the rate of decline in pension wealth after the ages at which pension wealth peaks and reduces the pension disincentive to delayed retirement. The vertical distance between the dotted and the solid lines measures the benefit of participation in the program. The benefit of participation is greatest for those who retire at older ages.

Individuals may respond to the change in incentives in different ways. At one extreme, employees might enter the DROP program at the age they would otherwise have retired, so that the increase in the age of retirement would equal the length of time spent in the program. At the other extreme, the program might have no effect on the age of final retirement, with employees spending the last few years of their career under the DROP program in order to change their pension entitlements.

The effect of the program on the finances of the pension plan depends on which of these two effects predominates. If employees simply extend their careers, then the program will be cost-neutral if the interest rate paid during the period of deferral equals the riskfree interest rate. ${ }^{12}$ During the period under review, the risk-free interest rate, as measured by the one-year Treasury, was generally less than the 4.5 percent credited to employee accounts, so an extension of careers would result in additional cost. If employees enter the DROP program at an earlier age than the age at which they would otherwise have retired, the program may have substantial costs. Employees will likely enter the DROP program only if participation increases the value of their pension wealth at their planned retirement age. If both the employee and the city face the same interest rate, the loss to the city, and the corresponding gain to the employee, equals the amount by which DROP participation increases the expected present value of the employee's pension wealth, evaluated at the risk-free rate, plus the foregone employee pension contributions. Figure 1 shows that the DROP program can result in significant increases

\footnotetext{
${ }^{11}$ Figure 1 does not incorporate the saving of employee pension contributions by individuals participating in the program.

${ }^{12}$ It is important to distinguish between the rate of interest used to determine funding schedules and the rate of interest used to value liabilities. The former rate can be chosen to reflect the higher expected return on equities and other risky investments. But one should use the risk-free rate when valuing liabilities.
} 
in pension wealth. For example, it increases the age-65 pension wealth of our stylized municipal employee by $\$ 23,500$, and the age-60 pension wealth of our stylized police/fire employee by $\$ 10,500 .^{13}$

\section{Data}

The City of Philadelphia provided administrative data containing employment records for 63,558 employees in pensionable occupations between 1990 and 2008. Although the data is considered reliable, it was not compiled specifically for the purposes of this study. As is often the case with studies of this type, a number of fields were missing. As we have an extremely large dataset, this will have little effect on our tests of statistical significance. Provided fields are missing at random, which we consider a reasonable assumption; it will also have no effect on our cost estimates.

Our sample attrition is as follows: Only 48 are elected officials, so we removed them from the sample. Next, we dropped the 1,079 employees whose gender was not recorded, 763 employees with missing or invalid dates of birth, and 9,686 employees whose date of commencement of pensionable service was not recorded. ${ }^{14}$ A total of 3,953 had a missing or invalid DROP enrollment date or retirement status date, or had inconsistent pension plan changes, leaving 48,029 employees. This equates to 404,099 person-year observations with employment and earnings data. We discarded 7,175 person-year observations where the employee left involuntarily. ${ }^{15}$ After restricting the sample to those person-year observations where the employee's age is between 19 and 78 (inclusive), and dropping those observations with missing or obviously incorrect data fields, we were left with 296,674 usable observations. Examples of unusable records include records where employees had not yet enrolled in a pension plan; years where data

\footnotetext{
${ }^{13}$ These amounts are discounted back to age 50 . The cost may be reduced if employees miscalculate the costs and benefits of participation in the program, if high discount-rate or liquidity-constrained employees participate in order to convert part of their pension into a lump sum, or if the risk-free interest rate the employee faces is lower than that which the pension plan can earn. We assumed a 3 percent real interest rate when calculating pension wealth, somewhat above the current risk-free rate. At lower assumed interest rates, pension wealth peaks at older ages.

${ }^{14}$ We do not regard the missing fields as evidence of poor record keeping, merely that the city had no administrative need to retain a permanent record of the data in question.

${ }^{15}$ A total of 21,030 employees separated or retired voluntarily, of whom 4,369 retired from DROP.
} 
on income is unavailable due to part-time service or no activity; and employees with multiple job-separation events. Of the remaining sample, 87,744 are police, 26,270 are fire, and 185,142 are municipal person-year records (8,988 police, 2,795 fire, and 22,315 municipal employees).

The records contain date of birth, gender, ethnicity, marital status, educational attainment, occupation, salary, dates of commencement and termination of service, the reason for termination, the date of entry in the DROP program, the employee's pension plan, and whether they are entitled to early vesting. ${ }^{16}$ We use this data to calculate each employee's early and full retirement ages, his current pension wealth, the age at which his pension wealth peaks, and his pension wealth at that time. The present value of current pension wealth depends on the assumptions made regarding mortality, interest, and inflation rates. We assume male and female population average mortality for the relevant birth cohort, as estimated by the Social Security Administration, but test the sensitivity of our results to alternative mortality assumptions. We assume an inflation rate of 2.5 percent, and consider real interest rates of 2 percent to 4 percent. ${ }^{17}$ When projecting pension wealth, we assume real wage growth of zero to 2.5 percent.

We use data on pay raises to indicate superior performance, since we do not have data on promotions and changes in job title were too infrequent to provide a usable performance indicator. ${ }^{18}$ We estimate a model that predicts pay raises as a function of year, job type (fire, police, municipal blue collar, municipal pink collar, municipal white collar), age, and years of service. ${ }^{19}$ We treat a pay raise in the top 20 percent of raises, relative to the predicted amount, as an indicator of superior performance and/or promotion.

\footnotetext{
${ }^{16}$ The occupation data was missing for 7,411 person-year observations of our initial sample, and we therefore omitted detailed occupational data from our regressions. We identified whether the employee was a police officer or firefighter, municipal employee, or elected official from the employee's pension plan.

${ }^{17}$ Real interest rates and anticipated inflation were higher in the early 1990s than today. As we will show later, our results are relatively insensitive to plausible variations in assumed interest rates.

${ }^{18}$ We have performance assessments for only about 40 percent of municipal employees. There are no assessments for fire department employees.

${ }^{19}$ We also include year dummies to capture time-varying aggregate economic effects, particularly timevarying inflation and unemployment rates, and city-wide budgetary decisions.
} 
Table 2 reports descriptive statistics for our sample and for the U.S. population as a whole from the Current Population Survey. Relative to the population, city employees are more likely to work in a blue-collar job, have less education, have longer tenure, and be members of a minority group. ${ }^{20}$ Police and fire officers are predominantly male. Average earnings of all classes of employees are higher than the national average. Employees who are eligible for the DROP program are older, have more education, have longer tenure, and earn more than the ineligible, reflecting the eligibility requirements discussed previously.

\section{Estimation Strategy}

The effect of the program on the age of retirement

We pool observations for full-time employees at each age between the years 1990 and 2008 who are either current members of the pension plan or were members of the plan prior to enrollment in the DROP program. We estimate the following probit model,

$$
P\left(R_{t}=1 \mid X_{t}\right)=\Phi\left(X_{t}^{\prime} B\right),
$$

in which our left-hand variable $\left(\mathrm{R}_{\mathrm{t}}\right)$ is a binary indicator for whether the worker left his job voluntarily or continued to work for the employer, and $X_{t}$ is a vector of regressors. ${ }^{21}$ On the right-hand side, our key regressor is the peak value of pension wealth accrual (peak minus current pension wealth, or zero if past the peak), as in Coile and Gruber (2000). ${ }^{22}$ We normalize peak value and pension wealth by earnings. ${ }^{23}$ We include a full set of pension program indicators: being at or past the peak (when the peak value of pension wealth accrual is set to zero) and when the employee first satisfies the age and service conditions for normal or early retirement during the year. When making the

\footnotetext{
${ }^{20}$ Assuming that the employee records for those with more education are no more likely to have missing education data.

${ }^{21}$ If an employee leaves his job involuntarily, for example, through firing with cause or the end of a temporary appointment, we drop that year's observation, but retain previous years' observations for the same employee.

${ }^{22}$ When calculating the age profile of pension wealth, we use assumed rates of inflation and real wage growth. We do not use the actual earnings path, which is unobserved for those who actually retire.

23 The "option value" measure of pension accrual in Samwick (1998) implicitly weighs pension income by earnings. We also control for earnings separately.
} 
above calculations, we ignore the effect of the DROP program on pension wealth. Following Coile (2004), we calculate gross pension benefits, without deducting the present value of future employee contributions. In our base case, we assume a 1.1 percent real wage growth and a 3 percent rate of time preference. ${ }^{24}$ In addition to our pension variables, we also control for a vector of demographic and job characteristics, which includes ethnicity, gender, marital status, educational attainment, occupation, tenure, the local unemployment rate, and a full set of age and year dummies.

We capture the effect of the DROP program by interacting a variable indicating that the employee is eligible for the program (DROP) with a vector of variables capturing the DROP incentives; the employee has not yet attained pre-DROP peak pension wealth, is at the age at which pre-DROP pension wealth is maximized, or is one to seven or more years past that age. If the interest rate payable on the DROP account equals the sum of the rate of inflation and real discount rate, and ignoring employee pension contributions, then employees should enter the DROP program when pension wealth peaks. Prior to that age, they are better off remaining in the pension plan. We therefore hypothesize that the DROP program should have no effect on retirements at ages prior to the age at which pension wealth peaks, and that the coefficient on DROP eligibility interacted with not having attained peak pension wealth should not be significantly different from zero. Additionally, DROP eligibility enables the employee to retire with peak pension wealth at any time during the four years following the age at which peak pension wealth is attained. ${ }^{25}$ We therefore hypothesize that DROP-eligible individuals who would have retired at the age that maximized the expected present value of their pension wealth will choose to retire anywhere from one to four years after that age. If our hypothesis is correct, and employees stay four years past their peak, the coefficient on DROP eligibility interacted with being either at one, two, or three years past peak pension wealth will be negative, and those on DROP eligibility interacted with being four to seven years

\footnotetext{
${ }^{24}$ We experimented with alternative assumptions regarding both of these parameters and found that plausible variations had little effect on our coefficient estimates.

${ }^{25}$ Ignoring the effect of being released from the obligation to contribute to the city pension plan.
} 
past the peak will be positive. ${ }^{26}$ But there may be heterogeneity in behavior, with some employees choosing to retire less than four years after their peak. To allow for the possibility that responses to the DROP program and the effects of our control variables might also vary with occupation, we also estimated separate models for fire, police, and municipal employees, and those enrolled in the pre-1988 pension plan.

To calculate the impact of the DROP program on the age of retirement, we must first estimate when DROP participants would have retired were it not for the existence of the program. For each employee participating in the DROP program, we identify the age at which they entered the DROP program and the age at which we predict they would have retired were it not for the program. We use the probit model for the appropriate employee group (fire, police, or municipal) to calculate the annual retirement hazard for each employee from the age at which that employee first became eligible for the program. We calculate the cumulative retirement hazard - the probability that the employee will still be employed after $t$ years. We note the percentile of the cumulative retirement hazard at the age at which the employee actually retires. We then use the same probit model to calculate the employee's cumulative retirement hazard, under the counterfactual that the employee was ineligible for the program. We assume that, in the absence of the DROP program, the employee would have retired at the age corresponding to the same percentile on this counterfactual cumulative retirement hazard.

\section{The effect of the program on pension costs}

The cost of the DROP program equals the sum of the following: 1) the annual amounts payable by the pension plan to DROP participants, minus the amounts that the pension plan would have paid had the employee retired at his counterfactual retirement age, discounted by a rate of interest and annual survival probabilities, and 2) the expected

\footnotetext{
${ }^{26}$ It is possible that some employees are prepared to continue working only when incented by large pension accruals. These employees would be unaffected by the DROP program. Other employees may retire only when incented by a large annual reduction in pension wealth. As illustrated by Figure 1, the DROP program has no significant effect on pension incentives at very advanced ages, as measured by the annual reduction in the expected present value of pension wealth (the lines are almost parallel), and the program may have little effect on the retirement patterns of the small number of employees working at these ages.
} 
present value of the employee pension contributions from the date of entry to the program to the counterfactual retirement date.

The calculations clearly depend on the assumed interest rate. The appropriate interest rate is the return on risk-free investments of appropriate duration, not the higher long-run expected rate of return on fund assets, which includes a risk premium. ${ }^{27}$ We use the Treasury STRIP term structure of interest rates in our calculations. To prevent our results being affected by changes in interest rates, we base our calculations on the interest rates prevailing at the time the employee would have retired were it not for the DROP program, and we test the sensitivity of our results to alternative assumed interest rates.

What type of employee does the DROP program induce to delay retirement?

In order to assess which employees are induced to work longer by the DROP program, we modify equation (7) by including interaction terms between DROP eligibility and our indicator of superior performance. ${ }^{28}$ Our base case model has a total of nine DROP eligibility interaction variables (not yet attained peak pension wealth, at peak and one to seven or more years past peak). Interacting all of the above with an employee-quality variable would create a model with a very large number of variables, the coefficients on which would be difficult to interpret. We therefore simplify our model to include variables indicating that the employee has not yet attained peak pension wealth, is at his peak, is one to four years or five or more years past peak. These are interacted with DROP eligibility and quality and with being both DROP eligible and high quality. Using our coefficient estimates, we calculate the differential impact of DROP eligibility on the cumulative retirement hazard of high-quality employees.

\section{Results}

The impact of the DROP program on voluntary retirement

\footnotetext{
${ }^{27}$ It is nonetheless appropriate to use the higher expected return on risky assets when determining a funding schedule.

${ }^{28}$ A potential concern is that there may be a relationship between mortality rates and patterns of DROP utilization. We defer analysis to future research, but hypothesize that there will be a weak relationship as the DROP program has relatively little effect on the duration of benefits.
} 
Table 3 compares the distribution of retirement, relative to when pension wealth peaks, for DROP-eligible employees with the distribution for employees who would have been eligible had the DROP program been in existence. ${ }^{29}$ A positive number denotes a prepeak year, and a negative number a post-peak year. Prior to the DROP program, most employees retired either at the age at which pension wealth peaked, or one or two years before or after. But post-DROP, there is a substantial decline in the percentages of fire and municipal employees retiring at the age at which pension wealth peaks or one year later, and increases in the percentages retiring at older ages.

The results of our econometric models reflect the above descriptive analysis. Tables 4A and B report marginal effects from estimating equation (7) for all employees and for occupational groups separately. A positive coefficient indicates a higher probability that a person voluntarily left his or her job and retired. One, two, and three stars indicate that the coefficient is significantly different from zero at the 5, 1, or 0.1 percent level. For example, the entry of 0.0370 in the "Fire/At peak pension wealth" cell indicates that fire department employees are 3.70 percentage points more likely to retire if they are at the age at which their pension wealth peaks, relative to the base case of not yet having attained peak pension wealth. Panel A reports results for pension variables, and Panel B results for non-pension variables. The first column shows the results for all employees. The remaining columns show results for fire, police, and municipal employees, respectively, and for employees enrolled in the pre-1988 pension plan. The coefficients and standard errors for the age and year dummies are reported in Table 4C in the appendix.

We find that pension accruals influence retirement rates of municipal employees and police officers. For these workers, a difference between current and peak pension wealth of an amount equal to current salary reduces retirement hazard by 0.41 percentage points and 0.99 percentage points, respectively. ${ }^{30}$ At age 42 , the mean relative peak difference

\footnotetext{
${ }^{29}$ The data is not adjusted for censoring. The DROP program may have resulted in some participants postponing retirement until after the end of the survey period.

${ }^{30}$ The probit marginal effect is evaluated at the means of the other variables for employees aged 42 . In contrast, Table 4A reports probit marginal effects evaluated at the means of the explanatory variables.
} 
is 3.97 and the mean salary is $\$ 40,896$ (in 2008 dollars) for municipal workers. Although the coefficient is similar in magnitude, pension accrual has only a marginally significant effect on the retirement hazard rates of fire employees, possibly reflecting the smaller sample size. Being at the age at which pension wealth is maximized increases the overall retirement hazard rate by 3.70, 1.18, and 4.85 percentage points for fire, police, and municipal workers, respectively. The effect is significant for all employee types but is significantly larger for municipal than for police employees. Employees in all three classes have significantly greater retirement hazards when they have passed the age at which pension wealth is maximized; the effect is significantly different from zero at the 1 percent level for all years past the peak pension wealth. The effect is greatest in the first few years past the peak for municipal workers.

Attaining the early retirement age has a significant and negative effect on the retirement hazard of municipal employees, and has no significant effect on fire or police employees. However, the hazard rates do spike at the full retirement age for municipal and police, the effect being greatest for municipal employees, who are 9.6 percentage points more likely to retire at that age, and smaller for the police employees who are 3.49 percentage points more likely to retire. This spike cannot be explained by financial considerations. Attaining the full retirement age has no effect on pension wealth accrual. Nor does it generally relax a liquidity constraint, because employees with 10 years of service can retire at the early retirement age. Nor does it coincide with eligibility for Medicare or Social Security. The full retirement age spike therefore suggests that social norms are playing a strong role in the retirement decision.

We now consider the impact of the DROP program on retirement hazard. As predicted, for municipal workers, the DROP program results in a decrease in retirement hazard before the age at which pension wealth peaks. The retirement hazard remains lower through the peak and the three subsequent years. For example, before the age at which pension wealth peaks, the retirement hazard of DROP-eligible municipal employees is 1.08 percentage points lower than that of ineligible employees, and 2.12, 1.74, 1.96, and 0.62 percentage points lower at the peak and one, two, and three years later, respectively. 
The retirement hazards of DROP-eligible employees spike four years and five years after the age at which pension wealth peaks, coinciding with the time limit for DROP participation.

The effect of the DROP program has the same general pattern, but slightly less pronounced, for police and fire employees. We still find a usually statistically significant decrease in the retirement hazard before, at, and one year after the age of peak pension wealth. We do measure significant decreases in the retirement hazard for DROP-eligible employees two and three years after peak pension wealth is achieved. The pattern reverses four and five years after peak pension wealth, with DROP-eligible employees having a higher retirement hazard than their non-eligible colleagues, which is consistent with the time limits of the DROP program. These increases fall short of statistical significance, possibly reflecting the less pronounced peak in pension wealth for these classes of employee.

A comparison between the coefficients on the non-pension wealth-related variables between DROP-eligible and DROP-ineligible employees reveals that they are generally similar in magnitude and are usually not significantly different. As might be expected, given the coefficients on the DROP variables in the models discussed above, the retirement hazard at the age at which pension wealth peaks and the three subsequent years is significantly and substantially lower for the DROP sample.

The non-pension variables in our model have the expected signs, as shown in Table 4B. Despite the extensive set of controls, the retirement hazard spikes at 65 for municipal workers, corresponding to Medicare eligibility. Although the effects of gender, marital status, and ethnicity are sometimes statistically significant, the effects are quantitatively small. Municipal employees are less likely to quit when the unemployment rate is high, but the unemployment rate has no significant effect on the quit rates of fire and police employees, possibly reflecting a wider range of post-retirement employment opportunities available to municipal employees. 
Figure 2 and 3 show the impact of the DROP program on the cumulative retirement hazards of fire and municipal employees, starting from the age at which they attain peak pension wealth. The employees are assumed to have the average non-pension characteristics of employees in the relevant occupation. Although the DROP program has little effect on the percent of employees still working five years after the peak, it does result in delayed retirement during that five-year period.

It is important to test how sensitive our estimates of the impact of the DROP program are to our underlying assumptions. Table 5 presents the marginal effects of the DROP program for municipal workers using different interest and wage growth rate assumptions. Column 1 presents the base case and is the same as presented in Table 4A and reproduced here for ease of comparison. Column 2 changes the real wage growth assumption from 1.1 to zero percent. Column 3 increases the real interest rate assumption from 3 percent to 4 percent, but maintains the 1.1 percent real wage growth assumption. The last column uses both the higher real interest rate (4 percent) and lower wage growth assumptions (zero percent) assumptions. ${ }^{31}$

It is striking that despite the changes in the underlying assumptions, the coefficient sign, magnitude, and significance are remarkably similar across the different specifications. ${ }^{32}$ At the normal retirement age, the retirement hazard increases from 0.096 to 0.115 percentage points. After the normal retirement age, the retirement hazard ranges from 4.84 to 5.53 percentage points. DROP eligibility continues to reduce the retirement hazard before the age at which the pension wealth maximum is attained (between 1.08 and 1.25 percentage points), at the age pension wealth is maximized (between 1.98 and 2.12 percentage points), and for the following three years (between 0.62 and 2.09 percentage points), depending on the year and specification. The spike in the retirement hazard remains in years four and five, corresponding to the DROP program rules, and

\footnotetext{
${ }^{31}$ We present only the results for municipal workers here. Results for fire and police employees are available upon request.

32 In only one case does the significance change. With a 1.1 percent real wage growth rate and 3 percent interest rate, the coefficient on being at the early retirement age is negative and statistically significant at the 90 percent level.
} 
ranges from 2.26 to 3.03 percentage points four years past the peak, the coefficients being statistically significant under each of our alternative assumptions.

\section{How much do employees delay retirement on average?}

Table 6 presents the average (and median) number of additional years worked due to the DROP program, by worker type. For comparison purposes, we also include estimates using the alternative interest rate and wage growth assumptions. We find that the DROP program had the largest impact on the retirement age of municipal workers. Our estimate of an average delay of 1.26 to 1.38 years is robust to alternative discount rate and wage growth assumptions. Fire employees were the next most impacted group, with a delay of .95 years, or 11 months, on average. This estimate is quite sensitive to the wage growth assumptions. At an assumed 0.5 percent wage growth, the delay falls to five months, and at zero percent wage growth, we cannot reject the hypothesis of no effect. Police officers are the least impacted by the DROP program, only delaying retirement by 0.183 years, or two months in our base case. Our data tabulations show that fire, police, and municipal employees who enrolled in the program prior to 2005 stayed an average of 45.6, 43.4, and 39.8 months in the program, the median duration being 48 months for all groups. ${ }^{33}$ Thus, employees in all classes entered the program between two and three and a half years prior to the age at which they would otherwise have retired.

\section{How much does the DROP program cost the employer?}

We first illustrate the calculation by reference to a hypothetical employee, and then present our estimates of average and total cost of the DROP program. ${ }^{34}$ The employee is a firefighter, born in June 1940, who commenced service in October 1960. He entered the DROP program in June 2001, when he was 61, and left exactly four years later in June 2005. At the time he entered the DROP program, his salary was $\$ 40,000$ a year. He is a member of the pre-1988 pension plan and is therefore entitled to the maximum pension of 100 percent of salary. He therefore received a lump sum of \$174,946 in June 2005, and a monthly pension of $\$ 3,333$ thereafter.

\footnotetext{
33 We do not yet know the duration of participation for employees who joined in 2005 and subsequent years. More than half the participants stayed for the 48 month maximum permitted.

34 This hypothetical employee is not representative and imposes substantially higher than average cost.
} 
Using our econometric model, we calculate that in the absence of the DROP, this employee would have retired in December 2003; the DROP program delayed his retirement by 18 months. Assuming 2.5 percent inflation and 1.1 percent real wage growth, he would by then have been earning \$42,955, and at the same 100 percent pension, would have been entitled to a pension of $\$ 3,580$ a month.

The effect of the employee's participation in the DROP program is to reduce the pension plan’s expenditure by \$3,580 a month for the 18-month period from December 2003 to June 2005. The pension plan suffers a one-time outflow of \$174,946 in June 2005. From July 2005 onward, the plan's outgoings are reduced by the difference in pension benefits of $\$ 247$ a month.

To arrive at our estimate of the cost of the DROP program, we discount the differences in cash payments by the term structure of interest rates and annual survival probabilities, assuming a zero mortality rate prior to December 2003. The DROP program increases the December 2003 expected present value of the pension plan’s liabilities by $\$ 74,735$. In addition to this, the DROP program results in the pension plan foregoing employee pension plan contributions from June 2001 to December 2003 with a total December 2003 present value of $\$ 6,469$. Thus, the total cost to the city in December 2003 is $\$ 81,204$.

We now investigate the sensitivity of this number to alternative assumptions regarding real wage growth and the interest rate used to discount the pension plan's liabilities. The cost of the DROP program will be lower at higher assumed rates of wage growth, because under the DROP program, pension benefits are based upon the employee's salary at the time he entered the program, not the higher salary at the time he would otherwise have retired. Ignoring the effect that the rate of wage growth has on the age at which the firefighter enters the DROP program, the total cost of the program to the pension plan increases to $\$ 91,631$ at a zero percent rate of wage growth and decreases to $\$ 72,588$ at a 2 percent rate of wage growth, all in nominal terms in December 2003. 
If the age of entry to the DROP program is simply the age at which the employee would otherwise have retired, the only effect of the program is to defer pension payments for the period of participation in the program. If the interest rate used to discount the plan's liabilities is less than the 4.5 percent a year credited to the DROP account, the program increases pension costs. Conversely, if the interest rate used to discount the plan's liabilities exceeds 4.5 percent, the program reduces pension costs. Table 7 shows that the term structure of interest rates over periods up to four years has generally been less than 4.5 percent over the period since the introduction of the program.

If, at the other extreme, the program has no effect on the age of retirement, it has the effect of accelerating payments from the pension plan. Instead of paying a monthly pension at retirement, the employee now receives a lump sum, plus a reduced pension. At higher assumed rates of return, relatively less weight is given to payments that will be made in the more distant future, and the program is now more expensive at higher assumed rates of return.

Our hypothetical firefighter delays retirement by 18 months, so he lies somewhere between the above extremes. It follows that our estimate of the cost of this employee to the program is relatively insensitive to the interest rate used to value the liability. At nominal interest rates of 2, 4, 6, and 8 percent, the cost is $\$ 71,663, \$ 74,881, \$ 76,488$, and $\$ 76,987$, respectively. All these amounts are somewhat less than the $\$ 81,204$ obtained when the term structure is used, reflecting the relatively low weight the term structure places on cost savings in more distant years.

Table 8A presents calculations for the average cost of the program for employees who retired in 2003 and subsequently through the DROP program. ${ }^{35}$ We present calculations

\footnotetext{
${ }^{35}$ We exclude people who retired 1999-2002. Employees retiring during this period might have chosen to enter the DROP program prior to 1999, had it been available. When estimating the cost to participants, we assume that the program had no effect on the age of retirement of non-participants, and allocate our estimate of the total cost of the program among participants.. It is possible that the program might have induced some eligible non-participants to delay retirement. Any increase or decrease in the pension costs
} 
based on the term structure of interest rates at the time the employee entered the program, and also at a 5, 8.25, and 11 percent interest rate, 8.25\% being the current expected return on plan assets. We assume a zero, 1.1, or 2 percent rate of real wage growth. In each case, employee response to the program is based on an econometric model incorporating the corresponding rate of wage growth and a 3 percent real interest rate.

Under our base case assumptions, per-employee costs are $\$ 38,700$ for fire, $\$ 24,300$ for police, and \$29,700 for municipal employees. The costs are somewhat lower at higher assumed rates of wage growth. This is because an employee who is induced to enter the DROP program at an age prior to that at which he would otherwise have retired reduces the salary upon which his pension benefits are calculated, and is not fully offset by changes in patterns of DROP utilization. The choice of assumed employee discount rate has relatively little impact on the estimates of the cost of the program. The program is substantially more costly when pension liabilities are valued using a higher discount rate. This is because participants enter the plan at significantly younger ages than the ages at which they would otherwise have retired, accelerating payments from the pension plan. Fire and police employees have identical plan rules, yet the average cost of the DROP program for fire employees is substantially greater. This reflects differences between the two groups both in the average age of retirement relative to peak pension wealth and in the impact of the DROP program on the age of retirement.

Table 8B shows estimates of the average annual cost of the program, based on the average number of new participants during the period 2000-2008, in millions of 2009 dollars. ${ }^{36}$ The cost estimates are somewhat higher at higher assumed interest rates, but are relatively insensitive to our assumptions regarding rates of wage increase and employee discount rates. At our preferred STRIP interest rates, the costs average $\$ 22.3$

of eligible non-participants will be offset by a corresponding decrease or increase in the estimated cost of participants, leaving our estimate of the total cost unchanged.

${ }^{36}$ We exclude 1999 because the number of new participants may have been inflated following the introduction of the program. We also exclude 2009 because the number of new participants was unusually high in that year, possibly reflecting concerns that the program might be terminated, and 2010 which is a part year. 
million a year, or $\$ 258$ million for all employees who entered the program prior to 31 December 2009.

Does the DROP program have a disproportionate effect on high-performing employees? Tables 9A (pension variables) and 9B (non-pension variables) report results for models with DROP eligibility interacted with our preferred indicator of being a high-quality employee. The DROP program significantly reduces the retirement hazard of highquality fire employees one to four years after the peak, but increases the retirement hazard of high-quality police employees. Our result is robust to sample restrictions and alternative specifications, and alternative cutoff points for determining high-quality employees. We conjecture that high-quality police employees may have good outside options, but that high-quality fire employees, whose skills are possibly less readily transferable to outside employers, have fewer such opportunities.

Table 10 reports estimates of comparisons of the impact of the DROP program on the mean delay of high-quality and average employees. The DROP program induces highquality fire employees to delay 18 months longer than their average-quality counterparts, but reduces the delay of high-quality police employees by 10 months. The impact of the DROP program on municipal employees does not appear to vary by employee quality.

\section{Conclusions}

We show that, in common with other defined benefit pension plans, the City of Philadelphia pension plan incorporates strong age-related retirement incentives. We show that city employees respond to these incentives. The DROP program reduces the disincentive to work at older ages, and employees respond to the DROP program by delaying retirement. But the age of retirement increases by substantially less than the average period of time spent in the DROP. Employees time their entry into the DROP to maximize the expected present value of their pension wealth and the cost to the city of providing their pension benefits. We estimate that the program imposes a significant cost to the pension plan and the city. Although our estimates are somewhat sensitive to the 
assumptions made regarding interest rates and wage growth, at no plausible combinations is it cost-neutral. 


\section{References}

City of Philadelphia. 2009. “Request for Proposals - Impact Evaluation of Philadelphia's Deferred Retirement Option Plan.” Office of the Director of Finance.

Coile, Courtney and Jonathan Gruber. 2000. “Social Security Incentives for Retirement.” In Themes in the Economics of Aging, David Wise, ed., 311-41. Chicago, IL: University of Chicago Press.

Coile, Courtney C. 2004. "Retirement Incentives and Couples’ Retirement Decisions.” Topics in Economic Analysis \& Policy 4(1): Article 17.

Friedberg, Leora and Anthony Webb. 2005. "Retirement and the Evolution of Pension Structure.” Journal of Human Resources Spring, 40(2): 281-308.

Samwick, Andrew. 1998. "New Evidence on Pensions, Social Security, and the Timing of Retirement.” Journal of Public Economics 70(2): 207-236.

Steffen, Karen. 2001. “Chapter 3: State Employee Pension Plans.” In Pensions in the Public Sector, Olivia Mitchell and Edwin Hustead, eds. Philadelphia, PA: University of Pennsylvania Press. 
Table 1: Pension Plan Parameters

\begin{tabular}{|l|r|r|r|r|}
\hline Hire date & \multicolumn{2}{|c|}{ Pre-1988 } & \multicolumn{2}{c|}{ Post-1988 } \\
\hline Employee type & Police and Fire & Municipal & Police and Fire & Municipal \\
\hline Percent accrual rate & & & & \\
\hline First 10 years & 2.50 & 2.50 & 2.20 & 2.20 \\
\hline $11-20$ years & 2.50 & 2.50 & 2.20 & 2.00 \\
\hline $21+$ years & 2.50 & 2.00 & 2.00 & 2.00 \\
\hline Normal retirement age & 45 & 55 & 50 & 60 \\
\hline Early retirement age & 40 & 50 & 40 & 52 \\
\hline Monthly early retirement reduction & $0.50 \%$ & $0.50 \%$ & $0.50 \%$ & $0.50 \%$ \\
\hline Source: Authors' calculations using administrative data. & & & \\
\hline
\end{tabular}


Table 2: Characteristics of Workers in City Pension Plan

\begin{tabular}{|c|c|c|c|c|c|c|c|}
\hline & $\begin{array}{c}\text { Population } \\
\text { (from CPS } \\
2006 \text { ) }\end{array}$ & All & Fire & Police & Municipal & $\begin{array}{l}\text { Pre-1988 } \\
\text { Pension Plan }\end{array}$ & $\begin{array}{l}\text { Eligible for } \\
\text { DROP }\end{array}$ \\
\hline $\mathrm{N}$ & & 296,674 & 26,270 & 87,744 & 185,142 & 147,037 & 29,467 \\
\hline Male & 0.537 & 0.633 & 0.967 & 0.773 & 0.519 & 0.651 & 0.681 \\
\hline Married & 0.868 & 0.470 & 0.631 & 0.411 & 0.470 & 0.538 & 0.581 \\
\hline \multicolumn{8}{|l|}{ Education: } \\
\hline No data & -- & 0.239 & 0.173 & 0.274 & 0.230 & 0.302 & 0.298 \\
\hline Less than High School & 0.096 & 0.080 & 0.100 & 0.042 & 0.095 & 0.092 & 0.081 \\
\hline High School/GED & 0.299 & 0.397 & 0.480 & 0.417 & 0.377 & 0.366 & 0.366 \\
\hline Some College - No Degree & 0.196 & 0.154 & 0.207 & 0.223 & 0.114 & 0.128 & 0.136 \\
\hline Four Years College & 0.304 & 0.092 & 0.035 & 0.043 & 0.124 & 0.070 & 0.070 \\
\hline Some Postgrad - No Degree & & 0.003 & 0.003 & 0.001 & 0.004 & 0.005 & 0.006 \\
\hline Masters Degree & 0.073 & 0.031 & 0.003 & 0.001 & 0.048 & 0.033 & 0.038 \\
\hline Doctoral Degree & 0.031 & 0.005 & 0.000 & 0.000 & 0.008 & 0.004 & 0.004 \\
\hline \multicolumn{8}{|l|}{ Occupation: } \\
\hline Blue collar & 0.388 & 0.703 & 1.000 & 1.000 & 0.522 & 0.685 & 0.700 \\
\hline Pink collar & 0.249 & 0.159 & -- & -- & 0.257 & 0.183 & 0.166 \\
\hline White Collar & 0.363 & 0.138 & -- & -- & 0.221 & 0.132 & 0.133 \\
\hline \multicolumn{8}{|l|}{ Ethnicity: } \\
\hline White & 0.700 & 0.466 & 0.721 & 0.591 & 0.371 & 0.499 & 0.602 \\
\hline Black & 0.104 & 0.479 & 0.239 & 0.340 & 0.579 & 0.471 & 0.371 \\
\hline Hispanic/Latino & 0.135 & 0.039 & 0.037 & 0.058 & 0.030 & 0.022 & 0.019 \\
\hline $\begin{array}{l}\text { Asian/Native } \\
\text { American/Multiracial/Other }\end{array}$ & 0.014 & 0.015 & 0.003 & 0.011 & 0.018 & 0.007 & 0.008 \\
\hline Unknown & -- & 0.001 & 0.000 & 0.000 & 0.001 & 0.001 & 0.000 \\
\hline Salary (2008 dollars) & $\$ 41,429$ & $\$ 46,278$ & $\$ 53,717$ & $\$ 53,335$ & $\$ 41,788$ & $\$ 47,563$ & $\$ 52,714$ \\
\hline Age & -- & 43.2 & 42.7 & 38.3 & 45.3 & 48.1 & 56.4 \\
\hline Years of Service & 7.5 & 11.9 & 15.3 & 11.8 & 11.3 & 18.2 & 24.7 \\
\hline
\end{tabular}


Table 3: Distribution of Retirement Relative to Peak Pension Wealth

\begin{tabular}{|c|c|c|c|c|c|c|}
\hline \multirow[b]{2}{*}{ Years-to-Peak } & \multicolumn{3}{|c|}{ Pre DROP } & \multicolumn{3}{|c|}{ Post DROP } \\
\hline & Fire & Police & Muni & Fire & Police & Muni \\
\hline-14 & $0.0 \%$ & $0.1 \%$ & $0.0 \%$ & $1.9 \%$ & $0.5 \%$ & $0.2 \%$ \\
\hline-13 & $0.4 \%$ & $0.1 \%$ & $0.2 \%$ & $1.9 \%$ & $1.1 \%$ & $0.2 \%$ \\
\hline-12 & $0.0 \%$ & $0.3 \%$ & $0.2 \%$ & $7.9 \%$ & $2.6 \%$ & $0.5 \%$ \\
\hline-11 & $0.2 \%$ & $0.4 \%$ & $0.4 \%$ & $4.2 \%$ & $1.4 \%$ & $0.4 \%$ \\
\hline-10 & $0.2 \%$ & $0.4 \%$ & $0.6 \%$ & $1.6 \%$ & $0.5 \%$ & $1.4 \%$ \\
\hline-9 & $0.8 \%$ & $0.3 \%$ & $0.8 \%$ & $0.6 \%$ & $1.7 \%$ & $1.1 \%$ \\
\hline-8 & $0.6 \%$ & $0.5 \%$ & $1.0 \%$ & $2.5 \%$ & $2.6 \%$ & $2.0 \%$ \\
\hline-7 & $1.0 \%$ & $0.5 \%$ & $1.6 \%$ & $4.3 \%$ & $4.3 \%$ & $3.1 \%$ \\
\hline-6 & $2.9 \%$ & $3.1 \%$ & $1.8 \%$ & $6.3 \%$ & $3.8 \%$ & $4.5 \%$ \\
\hline-5 & $6.7 \%$ & $4.9 \%$ & $2.0 \%$ & $15.6 \%$ & $4.8 \%$ & $7.4 \%$ \\
\hline-4 & $8.4 \%$ & $9.4 \%$ & $3.5 \%$ & $11.7 \%$ & $2.3 \%$ & $12.0 \%$ \\
\hline-3 & $7.9 \%$ & $9.3 \%$ & $5.0 \%$ & $7.0 \%$ & $8.6 \%$ & $8.2 \%$ \\
\hline-2 & $6.7 \%$ & $10.6 \%$ & $8.9 \%$ & $10.8 \%$ & $7.1 \%$ & $8.4 \%$ \\
\hline-1 & $12.6 \%$ & $12.3 \%$ & $18.1 \%$ & $6.1 \%$ & $10.3 \%$ & $14.5 \%$ \\
\hline 0 & $17.7 \%$ & $6.5 \%$ & $31.1 \%$ & $5.5 \%$ & $12.4 \%$ & $17.1 \%$ \\
\hline 1 & $5.3 \%$ & $3.5 \%$ & $6.6 \%$ & $1.0 \%$ & $3.9 \%$ & $4.0 \%$ \\
\hline 2 & $4.9 \%$ & $5.3 \%$ & $7.9 \%$ & $0.9 \%$ & $4.1 \%$ & $5.0 \%$ \\
\hline 3 & $6.7 \%$ & $7.0 \%$ & $2.3 \%$ & $1.9 \%$ & $5.3 \%$ & $1.7 \%$ \\
\hline 4 & $5.3 \%$ & $8.9 \%$ & $2.6 \%$ & $1.2 \%$ & $4.9 \%$ & $2.7 \%$ \\
\hline 5 & $6.5 \%$ & $8.2 \%$ & $1.7 \%$ & $1.8 \%$ & $5.2 \%$ & $1.8 \%$ \\
\hline 6 & $2.2 \%$ & $3.7 \%$ & $2.0 \%$ & $0.4 \%$ & $4.0 \%$ & $1.9 \%$ \\
\hline 7 & $2.0 \%$ & $1.3 \%$ & $1.3 \%$ & $0.9 \%$ & $3.2 \%$ & $0.9 \%$ \\
\hline 8 & $0.4 \%$ & $1.0 \%$ & $0.3 \%$ & $0.9 \%$ & $2.1 \%$ & $0.4 \%$ \\
\hline 9 & $0.2 \%$ & $1.0 \%$ & $0.4 \%$ & $0.4 \%$ & $1.3 \%$ & $0.3 \%$ \\
\hline 10 & $0.0 \%$ & $0.6 \%$ & $0.0 \%$ & $0.1 \%$ & $0.5 \%$ & $0.0 \%$ \\
\hline 11 & $0.2 \%$ & $0.5 \%$ & $0.0 \%$ & $0.1 \%$ & $0.6 \%$ & $0.0 \%$ \\
\hline 12 & $0.0 \%$ & $0.2 \%$ & $0.0 \%$ & $0.0 \%$ & $0.2 \%$ & $0.0 \%$ \\
\hline 13 & $0.0 \%$ & $0.2 \%$ & $0.0 \%$ & $0.0 \%$ & $0.1 \%$ & $0.0 \%$ \\
\hline 14 & $0.0 \%$ & $0.1 \%$ & $0.0 \%$ & $0.0 \%$ & $0.0 \%$ & $0.0 \%$ \\
\hline
\end{tabular}

Note: A negative years-to-peak indicates that the individual is past the age at which pension wealth is maximized. A positive value indicates that the individual has not yet attained that age.

Source: Authors' calculations using administrative data. 
Table 4 A: Regression Results: Marginal Effects Estimates on Pension Variables (at sample mean) (r=3\%, $g=1.1 \%)$

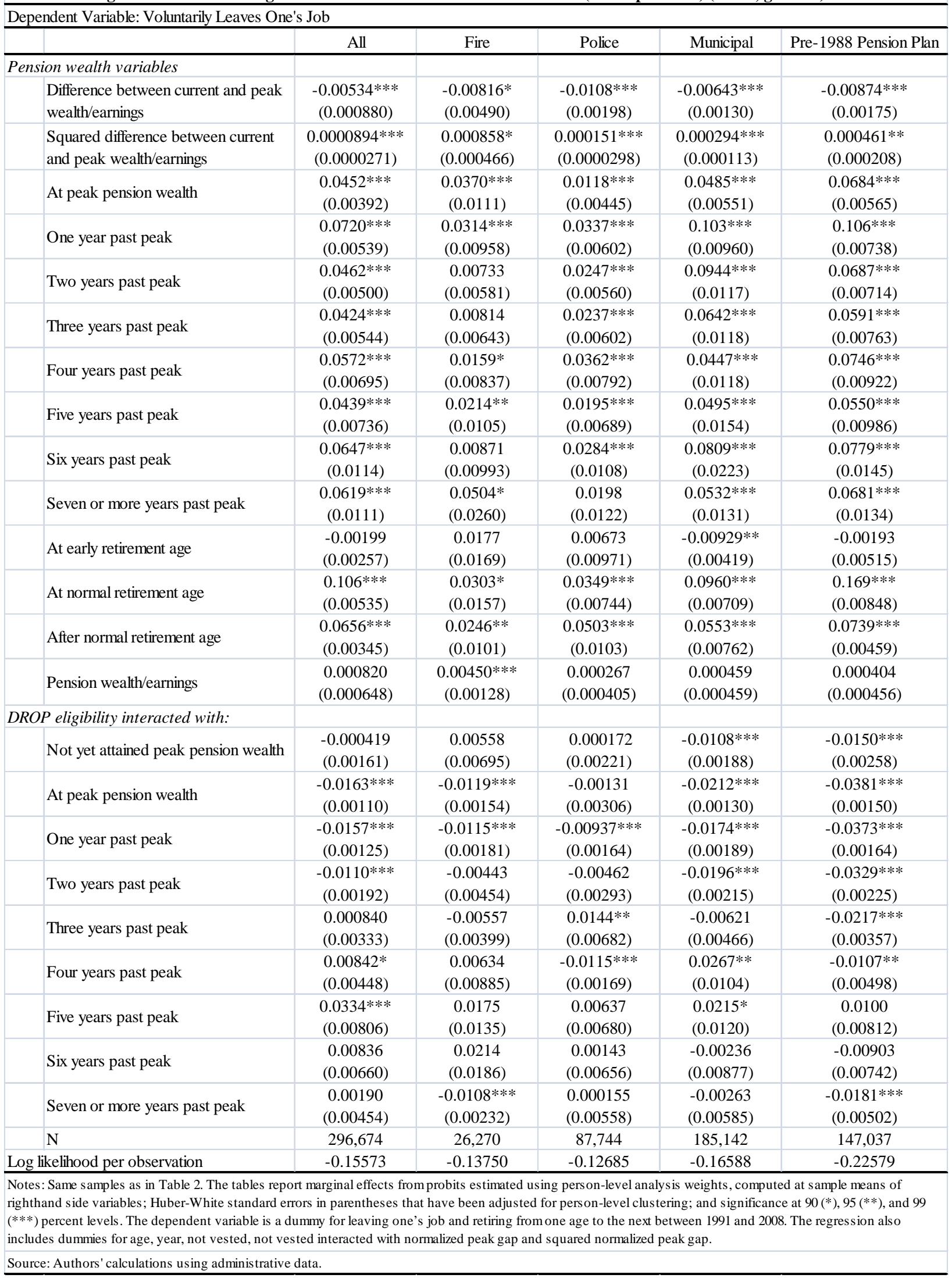


Table 4 B: Regression Results: Marginal Effects Estimates on Non-Pension Variables (at sample mean) Dependent Variable: Voluntarily Leaves One's Job

\begin{tabular}{|c|c|c|c|c|c|}
\hline & All & Fire & Police & Municipal & $\begin{array}{c}\text { Pre-1988 Pension } \\
\text { Plan }\end{array}$ \\
\hline Fire & $\begin{array}{l}-0.0210^{* * *} \\
(0.000605)\end{array}$ & - & - & - & $\begin{array}{l}-0.0241^{* * *} \\
(0.00177)\end{array}$ \\
\hline Police & $\begin{array}{l}-0.0177^{* * *} \\
(0.000813)\end{array}$ & -- & -- & - & $\begin{array}{r}-0.00315 \\
(0.00222)\end{array}$ \\
\hline Female & $\begin{array}{c}0.00205^{* *} \\
(0.000860)\end{array}$ & $\begin{array}{c}0.0185^{*} \\
(0.0109)\end{array}$ & $\begin{array}{l}0.00968^{* * * *} \\
(0.00169)\end{array}$ & $\begin{array}{l}-0.000619 \\
(0.00106)\end{array}$ & $\begin{array}{l}-0.000493 \\
(0.00163)\end{array}$ \\
\hline Married & $\begin{array}{c}0.000280 \\
(0.000604)\end{array}$ & $\begin{array}{c}-0.0000585 \\
(0.00139)\end{array}$ & $\begin{array}{c}0.000649 \\
(0.000765)\end{array}$ & $\begin{array}{r}-0.0000153 \\
(0.000841)\end{array}$ & $\begin{array}{l}0.00238^{* *} \\
(0.00118)\end{array}$ \\
\hline Marital Status Unknown & $\begin{array}{c}0.00969^{* * *} \\
(0.00155)\end{array}$ & $\begin{array}{c}0.00478 \\
(0.00529)\end{array}$ & $\begin{array}{c}0.00733^{* * *} \\
(0.00227)\end{array}$ & $\begin{array}{c}0.00647^{* * *} \\
(0.00190)\end{array}$ & $\begin{array}{l}0.0140^{* * *} \\
(0.00269)\end{array}$ \\
\hline \multicolumn{6}{|l|}{ Education: } \\
\hline No data & $\begin{array}{l}-0.00278^{* *} \\
(0.00123)\end{array}$ & $\begin{array}{c}0.00317 \\
(0.00424)\end{array}$ & $\begin{array}{l}0.0116^{* * *} \\
(0.00162)\end{array}$ & $\begin{array}{l}-0.00269^{*} \\
(0.00156)\end{array}$ & $\begin{array}{l}-0.00254 \\
(0.00270)\end{array}$ \\
\hline Less than high school & $\begin{array}{c}-0.00367^{* * * * *} \\
(0.00140)\end{array}$ & $\begin{array}{r}0.000185 \\
(0.00359)\end{array}$ & $\begin{array}{c}-0.00587^{* * * *} \\
(0.00184)\end{array}$ & $\begin{array}{l}-0.00313^{*} \\
(0.00181)\end{array}$ & $\begin{array}{r}0.000389 \\
(0.00319)\end{array}$ \\
\hline High School/GED & $\begin{array}{c}-0.00752^{* * * *} \\
(0.00119)\end{array}$ & $\begin{array}{l}-0.00247 \\
(0.00315)\end{array}$ & $\begin{array}{l}-0.0108^{* * *} \\
(0.00181)\end{array}$ & $\begin{array}{c}-0.00587^{* * * *} \\
(0.00152)\end{array}$ & $\begin{array}{l}-0.00325 \\
(0.00263)\end{array}$ \\
\hline Some College - No Degree & $\begin{array}{c}-0.00552^{* * *} \\
(0.00119)\end{array}$ & $\begin{array}{l}-0.00100 \\
(0.00314)\end{array}$ & $\begin{array}{c}-0.00610^{* * *} \\
(0.00167)\end{array}$ & $\begin{array}{c}-0.00479^{* * * *} \\
(0.00160)\end{array}$ & $\begin{array}{l}-0.00263 \\
(0.00280)\end{array}$ \\
\hline Some Postgrad - No Degree & $\begin{array}{l}-0.00606^{*} \\
(0.00365)\end{array}$ & $\begin{array}{l}-0.0124^{* * *} \\
(0.00121)\end{array}$ & $\begin{array}{l}0.00642 \\
(0.0102)\end{array}$ & $\begin{array}{c}-0.00245 \\
(0.00477)\end{array}$ & $\begin{array}{c}-0.00503 \\
(0.00691)\end{array}$ \\
\hline Masters Degree & $\begin{array}{c}0.00620^{* * *} \\
(0.00230)\end{array}$ & $\begin{array}{l}-0.00440 \\
(0.00537)\end{array}$ & $\begin{array}{c}-0.00967^{* * *} \\
(0.00198)\end{array}$ & $\begin{array}{c}0.00988^{* * *} \\
(0.00261)\end{array}$ & $\begin{array}{c}0.0117^{* *} \\
(0.00484)\end{array}$ \\
\hline Doctoral Degree & $\begin{array}{l}0.0411^{* * * *} \\
(0.00937)\end{array}$ & - & $\begin{array}{l}-0.0151^{\text {***** }} \\
(0.000573)\end{array}$ & $\begin{array}{l}0.0474^{* * * *} \\
{[0.00977)}\end{array}$ & $\begin{array}{l}0.00687 \\
{[0.0125)}\end{array}$ \\
\hline \multicolumn{6}{|l|}{ Occupation: } \\
\hline Pink Collar & $\begin{array}{c}-0.00432^{* * *} \\
(0.000898)\end{array}$ & - & -- & $\begin{array}{c}-0.00344^{* * *} \\
(0.00106)\end{array}$ & $\begin{array}{c}-0.00651^{* * *} \\
(0.00182)\end{array}$ \\
\hline White Collar & $\begin{array}{c}-0.00296^{* * *} \\
(0.00113)\end{array}$ & -- & -- & $\begin{array}{l}-0.000882 \\
(0.00135)\end{array}$ & $\begin{array}{c}-0.00625^{* * * *} \\
(0.00229)\end{array}$ \\
\hline Managerial & $\begin{array}{c}-0.00230^{* * * *} \\
(0.000801)\end{array}$ & $\begin{array}{c}-0.00820^{\text {**** }} \\
(0.00149)\end{array}$ & $\begin{array}{r}0.000579 \\
(0.00112)\end{array}$ & $\begin{array}{l}-0.00308^{* *} \\
(0.00128)\end{array}$ & $\begin{array}{c}-0.00454^{* * *} \\
(0.00142)\end{array}$ \\
\hline \multicolumn{6}{|l|}{ Ethnicity: } \\
\hline White & $\begin{array}{l}0.00175^{* * *} \\
(0.000632)\end{array}$ & $\begin{array}{l}-0.00391^{* *} \\
(0.00169)\end{array}$ & $\begin{array}{c}0.000576 \\
(0.000871)\end{array}$ & $\begin{array}{c}0.00153^{*} \\
(0.000859)\end{array}$ & $\begin{array}{c}-0.00278^{* *} \\
(0.00126)\end{array}$ \\
\hline Hispanic/Latino & $\begin{array}{l}-0.00274^{*} \\
(0.00156)\end{array}$ & $\begin{array}{c}-0.00531 \\
(0.00339)\end{array}$ & $\begin{array}{l}-0.000378 \\
(0.00204)\end{array}$ & $\begin{array}{c}-0.00309 \\
(0.00223)\end{array}$ & $\begin{array}{c}-0.00182 \\
(0.00389)\end{array}$ \\
\hline Asian/Native American/Multiracial/Oth & $\begin{array}{l}-0.00469^{*} \\
{[0.00248)}\end{array}$ & $\begin{array}{c}0.0322 \\
(0.0235)\end{array}$ & $\begin{array}{c}0.00771 \\
(0.00586)\end{array}$ & $\begin{array}{c}-0.00998^{* * * *} \\
(0.00272)\end{array}$ & $\begin{array}{l}-0.0200^{* * * *} \\
(0.00530)\end{array}$ \\
\hline Unknown & $\begin{array}{l}0.0729^{* * * *} \\
(0.0172)\end{array}$ & - & $\begin{array}{c}0.0462 \\
(0.0348)\end{array}$ & $\begin{array}{c}0.0750^{* * * *} \\
(0.0194)\end{array}$ & $\begin{array}{c}0.0545^{* * * *} \\
(0.0178)\end{array}$ \\
\hline Earnings (thousands of 2008 Dollars) & $\begin{array}{l}-0.000720^{* * * *} \\
(0.0000713)\end{array}$ & $\begin{array}{l}0.00298^{* * *} \\
(0.000870)\end{array}$ & $\begin{array}{c}0.000625^{* * * *} \\
(0.000150)\end{array}$ & $\begin{array}{c}-0.000845^{* * *} \\
(0.0000957)\end{array}$ & $\begin{array}{c}-0.000871^{* * * *} \\
(0.000130)\end{array}$ \\
\hline Squared Earnings (thousands of 2008 Dollars) & $\begin{array}{l}0.00000395^{* * *} \\
(0.000000674)\end{array}$ & $\begin{array}{r}-0.0000206^{* * *} \\
(0.00000625)\end{array}$ & $\begin{array}{l}0.00000266^{* * *} \\
(0.000000797)\end{array}$ & $\begin{array}{c}0.00000442^{* * * *} \\
(0.00000102)\end{array}$ & $\begin{array}{c}0.00000478^{* * * *} \\
(0.00000114)\end{array}$ \\
\hline Years of Service & $\begin{array}{l}0.00425^{* * *} \\
(0.000373)\end{array}$ & $\begin{array}{l}0.00350^{*} \\
(0.00198)\end{array}$ & $\begin{array}{c}0.00678^{* * *} \\
(0.00101)\end{array}$ & $\begin{array}{l}0.00502^{* * *} \\
(0.000494)\end{array}$ & $\begin{array}{c}-0.000258 \\
(0.000918)\end{array}$ \\
\hline Squared Years of Service & $\begin{array}{l}-0.000113^{* * * *} \\
(0.0000210)\end{array}$ & $\begin{array}{c}-0.000126 \\
(0.0000800)\end{array}$ & $\begin{array}{l}-0.000203^{* * * *} \\
(0.0000472)\end{array}$ & $\begin{array}{c}-0.000178^{* * *} \\
(0.0000257)\end{array}$ & $\begin{array}{l}0.000114^{* * *} \\
(0.0000400)\end{array}$ \\
\hline Cubed Years of Service & $\begin{array}{l}0.00000115^{* * *} \\
(0.000000345)\end{array}$ & $\begin{array}{c}0.00000156 \\
(0.00000108)\end{array}$ & $\begin{array}{l}0.00000242^{* * *} \\
(0.000000708)\end{array}$ & $\begin{array}{l}0.00000223^{* * *} \\
(0.000000409)\end{array}$ & $\begin{array}{c}-0.00000190^{* * *} \\
(0.000000563)\end{array}$ \\
\hline Unemployment Rate & $\begin{array}{c}-0.0277^{* * * *} \\
(0.00302)\end{array}$ & $\begin{array}{c}0.00209 \\
(0.00555)\end{array}$ & $\begin{array}{c}-0.00374 \\
(0.00380)\end{array}$ & $\begin{array}{c}-0.0441^{* * *} \\
(0.00423)\end{array}$ & $\begin{array}{c}0.0179^{* *} \\
(0.00738)\end{array}$ \\
\hline
\end{tabular}


Table 5: Sensitivity Analysis

\begin{tabular}{|c|c|c|c|c|}
\hline \multicolumn{5}{|l|}{ Dependent Variable: Voluntarily Leaves One's Job } \\
\hline & Base Case: $\mathrm{r}=3, \mathrm{~g}=1.1$ & $r=3, g=0$ & $r=4, g=1.1$ & $r=4, g=0$ \\
\hline & 5.1 & 5.2 & 5.3 & 5.4 \\
\hline \multicolumn{5}{|l|}{ Pension wealth variables } \\
\hline $\begin{array}{l}\text { Pension wealth/earnings (thousands of } 2008 \\
\text { dollars) }\end{array}$ & $\begin{array}{c}0.000459 \\
(0.000459)\end{array}$ & $\begin{array}{c}0.000523 \\
(0.000500)\end{array}$ & $\begin{array}{c}0.000587 \\
(0.000557)\end{array}$ & $\begin{array}{c}0.000649 \\
(0.000596)\end{array}$ \\
\hline $\begin{array}{l}\text { Difference between current and peak } \\
\text { wealth/earnings }\end{array}$ & $\begin{array}{c}-0.00643^{* * *} \\
(0.00130)\end{array}$ & $\begin{array}{c}-0.00440 * * * \\
(0.00134)\end{array}$ & $\begin{array}{c}-0.00539 * * * \\
(0.00155)\end{array}$ & $\begin{array}{c}-0.00390 * * \\
(0.00166)\end{array}$ \\
\hline $\begin{array}{l}\text { Squared difference between current and peak } \\
\text { wealth/earnings }\end{array}$ & $\begin{array}{c}0.000294 * * * \\
(0.000113)\end{array}$ & $\begin{array}{l}0.000171^{* *} \\
(0.0000843)\end{array}$ & $\begin{array}{c}0.000299 * * \\
(0.000141)\end{array}$ & $\begin{array}{c}0.000171 \\
(0.000119)\end{array}$ \\
\hline At peak pension wealth & $\begin{array}{l}0.0485 * * * \\
(0.00551)\end{array}$ & $\begin{array}{l}0.0433 * * * \\
(0.00530)\end{array}$ & $\begin{array}{c}0.0394 * * * \\
(0.00535)\end{array}$ & $\begin{array}{c}0.0355 * * * \\
(0.00528)\end{array}$ \\
\hline One year past peak & $\begin{array}{l}0.103 * * * \\
(0.00960)\end{array}$ & $\begin{array}{l}0.124 * * * \\
(0.0109)\end{array}$ & $\begin{array}{l}0.117 * * * \\
(0.0105)\end{array}$ & $\begin{array}{l}0.128 * * * \\
(0.0116)\end{array}$ \\
\hline Two years past peak & $\begin{array}{c}0.0944^{* * *} \\
(0.0117)\end{array}$ & $\begin{array}{c}0.119 * * * \\
(0.0133)\end{array}$ & $\begin{array}{c}0.105^{* * *} \\
(0.0122)\end{array}$ & $\begin{array}{r}0.117 * * * \\
(0.0132)\end{array}$ \\
\hline Three years past peak & $\begin{array}{c}0.0642^{* * *} \\
(0.0118)\end{array}$ & $\begin{array}{c}0.0907 * * * \\
(0.0137)\end{array}$ & $\begin{array}{c}0.0930^{* * *} \\
(0.0131)\end{array}$ & $\begin{array}{c}0.102 * * * \\
(0.0139)\end{array}$ \\
\hline Four years past peak & $\begin{array}{l}0.0447 * * * \\
(0.0118)\end{array}$ & $\begin{array}{c}0.0459 * * * \\
(0.0115)\end{array}$ & $\begin{array}{c}0.0470^{* * *} \\
(0.0112)\end{array}$ & $\begin{array}{c}0.0602 * * * \\
(0.0121)\end{array}$ \\
\hline Five years past peak & $\begin{array}{c}0.0495^{* * *} \\
(0.0154)\end{array}$ & $\begin{array}{c}0.0485^{* * *} \\
(0.0139)\end{array}$ & $\begin{array}{c}0.0564 * * * \\
(0.0140)\end{array}$ & $\begin{array}{c}0.0790 * * * \\
(0.0156)\end{array}$ \\
\hline Six years past peak & $\begin{array}{c}0.0809 * * * \\
(0.0223)\end{array}$ & $\begin{array}{c}0.0624 * * * \\
(0.0166)\end{array}$ & $\begin{array}{c}0.0777 * * * \\
(0.0178)\end{array}$ & $\begin{array}{c}0.0776 * * * \\
(0.0172)\end{array}$ \\
\hline Seven or more years past peak & $\begin{array}{c}0.0532 * * * \\
(0.0131)\end{array}$ & $\begin{array}{l}0.0696 * * * \\
(0.0126)\end{array}$ & $\begin{array}{c}0.0700^{* * *} \\
(0.0128)\end{array}$ & $\begin{array}{c}0.0832 * * * \\
(0.0133)\end{array}$ \\
\hline At early retirement age & $\begin{array}{c}-0.00929 * * \\
(0.00419)\end{array}$ & $\begin{array}{l}-0.00823^{*} \\
(0.00422)\end{array}$ & $\begin{array}{l}-0.00760 * \\
(0.00435)\end{array}$ & $\begin{array}{l}-0.00650 \\
(0.00441)\end{array}$ \\
\hline At normal retirement age & $\begin{array}{c}0.0960 * * * \\
(0.00709)\end{array}$ & $\begin{array}{l}0.102 * * * \\
(0.00740)\end{array}$ & $\begin{array}{l}0.109 * * * \\
(0.00785)\end{array}$ & $\begin{array}{l}0.115^{* * *} \\
(0.00818)\end{array}$ \\
\hline After normal retirement age & $\begin{array}{c}0.0553 * * * \\
(0.00762)\end{array}$ & $\begin{array}{c}0.0532 * * * \\
(0.00755)\end{array}$ & $\begin{array}{c}0.0504 * * * \\
(0.00738)\end{array}$ & $\begin{array}{l}0.0484^{* * *} \\
(0.00731)\end{array}$ \\
\hline \multicolumn{5}{|l|}{ DROP eligibility interacted with: } \\
\hline Not yet attained peak pension wealth & $\begin{array}{c}-0.0108 * * * \\
(0.00188)\end{array}$ & $\begin{array}{c}-0.0110 * * * \\
(0.00202)\end{array}$ & $\begin{array}{c}-0.0125^{* * * *} \\
(0.00200)\end{array}$ & $\begin{array}{c}-0.0117 * * * \\
(0.00223)\end{array}$ \\
\hline At peak pension wealth & $\begin{array}{c}-0.0212 * * * \\
(0.00130)\end{array}$ & $\begin{array}{c}-0.0198 * * * \\
(0.00137)\end{array}$ & $\begin{array}{c}-0.0210^{* * * *} \\
(0.00133)\end{array}$ & $\begin{array}{c}-0.0207 * * * \\
(0.00132)\end{array}$ \\
\hline One year past peak & $\begin{array}{c}-0.0174 * * * \\
(0.00189)\end{array}$ & $\begin{array}{c}-0.0181 * * * \\
(0.00181)\end{array}$ & $\begin{array}{c}-0.0187 * * * \\
(0.00171)\end{array}$ & $\begin{array}{c}-0.0186 * * * \\
(0.00172)\end{array}$ \\
\hline Two years past peak & $\begin{array}{c}-0.0196 * * * \\
(0.00215)\end{array}$ & $\begin{array}{c}-0.0209 * * * \\
(0.00192)\end{array}$ & $\begin{array}{c}-0.0198 * * * \\
(0.00201)\end{array}$ & $\begin{array}{c}-0.0199 * * * \\
(0.00196)\end{array}$ \\
\hline Three years past peak & $\begin{array}{l}-0.00621 \\
(0.00466)\end{array}$ & $\begin{array}{c}-0.0112 * * * \\
(0.00375)\end{array}$ & $\begin{array}{c}-0.0148^{* * *} \\
(0.00304)\end{array}$ & $\begin{array}{c}-0.0145^{* * *} \\
(0.00302)\end{array}$ \\
\hline Four years past peak & $\begin{array}{l}0.0267 * * \\
(0.0104)\end{array}$ & $\begin{array}{c}0.0303^{* * *} \\
(0.0104)\end{array}$ & $\begin{array}{c}0.0288^{* * *} \\
(0.00957)\end{array}$ & $\begin{array}{c}0.0226 * * * \\
(0.00839)\end{array}$ \\
\hline Five years past peak & $\begin{array}{l}0.0215^{*} \\
(0.0120)\end{array}$ & $\begin{array}{c}0.0247 * * \\
(0.0114)\end{array}$ & $\begin{array}{c}0.0232 * * \\
(0.0103)\end{array}$ & $\begin{array}{c}0.0137 \\
(0.00830)\end{array}$ \\
\hline Six years past peak & $\begin{array}{l}-0.00236 \\
(0.00877)\end{array}$ & $\begin{array}{l}0.00956 \\
(0.0100)\end{array}$ & $\begin{array}{c}0.00432 \\
(0.00846)\end{array}$ & $\begin{array}{c}0.00757 \\
(0.00875)\end{array}$ \\
\hline Seven or more years past peak & $\begin{array}{l}-0.00263 \\
(0.00585)\end{array}$ & $\begin{array}{l}-0.00641 \\
(0.00450)\end{array}$ & $\begin{array}{l}-0.00469 \\
(0.00459)\end{array}$ & $\begin{array}{l}-0.00647 \\
(0.00410)\end{array}$ \\
\hline $\mathrm{N}$ & 185,142 & 185,142 & 185,142 & 185,142 \\
\hline Log likelihood per observation & -0.16588 & -0.16561 & -0.16558 & -0.16544 \\
\hline \multicolumn{5}{|c|}{$\begin{array}{l}\text { Notes: Same samples as in Table } 2 \text {. The tables report marginal effects from probits estimated using person-level analysis weights, computed at sample means of } \\
\text { righthand side variables; Huber-White standard errors in parentheses that have been adjusted for person-level clustering; and significance at } 90(*), 95(* *) \text {, and } 99 \\
(* * *) \text { percent levels. The dependent variable is a dummy for leaving one’s job and retiring from one age to the next between } 1991 \text { and } 2008 \text {. The regression also includes } \\
\text { age, year, marital status, education, gender, ethnicity and occupation dummies, as well as dummies for not vested, not vested interacted with normalized peak gap and } \\
\text { squared normalized peak gap. }\end{array}$} \\
\hline \multicolumn{5}{|l|}{ Source: Authors' calculations using administrative data. } \\
\hline
\end{tabular}


Table 6: Retirement Delay (in Years) Due to DROP

\begin{tabular}{|c|c|c|c|c|c|}
\hline$r$ & $g$ & & Fire & Police & Municipal \\
\hline \multirow{8}{*}{$3 \%$} & \multirow{2}{*}{$0 \%$} & Mean & -0.337 & -0.358 & 1.304 \\
\hline & & Median & -0.485 & -0.407 & 1.158 \\
\hline & \multirow{2}{*}{$0.5 \%$} & Mean & 0.421 & -0.149 & 1.292 \\
\hline & & Median & 0.434 & -0.118 & 1.158 \\
\hline & \multirow{2}{*}{$1.1 \%$} & Mean & 0.952 & 0.183 & 1.270 \\
\hline & & Median & 0.793 & 0.105 & 1.162 \\
\hline & \multirow{2}{*}{$2.0 \%$} & Mean & 1.121 & 0.455 & 1.263 \\
\hline & & Median & 0.896 & 0.452 & 1.161 \\
\hline \multirow{8}{*}{$4 \%$} & \multirow{2}{*}{$0 \%$} & Mean & -0.029 & -0.541 & 1.384 \\
\hline & & Median & 0.000 & -0.599 & 1.287 \\
\hline & \multirow{2}{*}{$0.5 \%$} & Mean & 0.209 & -0.303 & 1.366 \\
\hline & & Median & 0.182 & -0.319 & 1.281 \\
\hline & \multirow{2}{*}{$1.1 \%$} & Mean & 0.827 & -0.134 & 1.356 \\
\hline & & Median & 0.737 & -0.176 & 1.284 \\
\hline & \multirow{2}{*}{$2 \%$} & Mean & 0.888 & 0.183 & 1.309 \\
\hline & & Median & 0.849 & 0.168 & 1.283 \\
\hline
\end{tabular}

Source: Authors' calculations using administrative data.

Table 7: US Treasury Bond Annual Yields (2000 - 2009)

\begin{tabular}{|c|c|c|c|c|c|c|c|c|c|c|}
\hline Year / Term & 3 month & 6 month & 1 year & 2 year & 3 year & 5 year & 7 year & 10 year & 20 year & 30 year* \\
\hline 1999 & 4.78 & 4.95 & 5.08 & 5.43 & 5.49 & 5.55 & 5.79 & 5.65 & 6.20 & 5.87 \\
\hline 2000 & 6.00 & 6.17 & 6.11 & 6.26 & 6.22 & 6.16 & 6.20 & 6.03 & 6.23 & 5.94 \\
\hline 2001 & 3.48 & 3.45 & 3.49 & 3.83 & 4.09 & 4.56 & 4.88 & 5.02 & 5.63 & 5.49 \\
\hline 2002 & 1.64 & 1.72 & 2.00 & 2.64 & 3.10 & 3.82 & 4.30 & 4.61 & 5.43 & 5.43 \\
\hline 2003 & 1.03 & 1.08 & 1.24 & 1.65 & 2.10 & 2.97 & 3.52 & 4.01 & 4.96 & 5.05 \\
\hline 2004 & 1.40 & 1.61 & 1.89 & 2.38 & 2.78 & 3.43 & 3.87 & 4.27 & 5.04 & 5.11 \\
\hline 2005 & 3.22 & 3.50 & 3.62 & 3.85 & 3.93 & 4.05 & 4.15 & 4.29 & 4.64 & 4.56 \\
\hline 2006 & 4.85 & 5.00 & 4.94 & 4.82 & 4.77 & 4.75 & 4.76 & 4.80 & 5.00 & 4.88 \\
\hline 2007 & 4.48 & 4.62 & 4.53 & 4.36 & 4.35 & 4.43 & 4.51 & 4.63 & 4.91 & 4.84 \\
\hline 2008 & 1.40 & 1.66 & 1.83 & 2.01 & 2.24 & 2.80 & 3.17 & 3.66 & 4.36 & 4.28 \\
\hline 2009 & 0.15 & 0.28 & 0.47 & 0.96 & 1.43 & 2.20 & 2.82 & 3.26 & 4.11 & 4.08 \\
\hline
\end{tabular}


Table 8A: Cost per participant (in 2009 dollars) due to DROP

\begin{tabular}{|c|c|c|c|c|c|c|c|c|c|c|c|c|c|c|}
\hline & & & \multicolumn{3}{|c|}{ STRIP Rates } & \multicolumn{3}{|c|}{ Constant 5\% Nominal } & \multicolumn{3}{|c|}{ Constant $8.25 \%$ Nominal } & \multicolumn{3}{|c|}{ Constant $11 \%$ Nominal } \\
\hline $\mathrm{r}$ & $\bar{g}$ & & Fire & Police & Municipal & Fire & Police & Municipal & Fire & Police & Municipal & Fire & Police & Municipal \\
\hline \multirow{8}{*}{$3 \%$} & \multirow{2}{*}{$0 \%$} & Mean & 51,800 & 26,200 & 29,200 & 60,800 & 34,000 & 29,500 & 96,200 & 67,000 & 35,300 & 117,000 & 86,000 & 38,200 \\
\hline & & Median & 48,600 & 17,200 & 16,100 & 61,100 & 25,500 & 16,400 & 92,500 & 59,100 & 22,100 & 110,400 & 80,500 & 23,400 \\
\hline & \multirow{2}{*}{$0.5 \%$} & Mean & 43,000 & 26,100 & 29,300 & 46,400 & 32,000 & 29,600 & 72,600 & 62,800 & 35,500 & 87,300 & 80,400 & 38,400 \\
\hline & & Median & 37,900 & 18,300 & 16,100 & 42,000 & 20,900 & 16,400 & 65,700 & 50,900 & 21,400 & 80,800 & 70,000 & 23,400 \\
\hline & \multirow{2}{*}{$1.1 \%$} & Mean & 38,700 & 24,300 & 29,700 & 40,600 & 27,700 & 30,000 & 60,100 & 54,700 & 35,900 & 70,600 & 69,800 & 38,900 \\
\hline & & Median & 35,600 & 17,100 & 16,000 & 35,700 & 18,500 & 16,000 & 53,400 & 46,900 & 20,900 & 62,800 & 63,300 & 23,500 \\
\hline & \multirow{2}{*}{$2.0 \%$} & Mean & 30,500 & 22,300 & 28,900 & 32,900 & 24,500 & 29,300 & 51,200 & 48,600 & 35,400 & 61,000 & 61,800 & 38,600 \\
\hline & & Median & 29,000 & 16,000 & 15,100 & 31,100 & 18,000 & 14,900 & 50,600 & 42,600 & 19,500 & 61,900 & 57,400 & 22,700 \\
\hline \multirow{8}{*}{$4 \%$} & \multirow{2}{*}{$0 \%$} & Mean & 43,300 & 24,200 & 28,200 & 51,200 & 33,900 & 28,400 & 82,700 & 69,700 & 33,900 & 100,800 & 90,400 & 36,600 \\
\hline & & Median & 44,600 & 17,100 & 15,500 & 49,500 & 24,200 & 15,600 & 76,400 & 63,400 & 20,600 & 95,500 & 85,000 & 23,000 \\
\hline & \multirow{2}{*}{$0.5 \%$} & Mean & 40,700 & 24,900 & 28,200 & 47,200 & 31,600 & 28,500 & 75,800 & 64,400 & 34,000 & 91,900 & 83,200 & 36,800 \\
\hline & & Median & 39,700 & 16,500 & 15,400 & 47,100 & 22,600 & 15,400 & 71,000 & 55,000 & 20,700 & 87,000 & 74,300 & 23,100 \\
\hline & \multirow[b]{2}{*}{$1.1 \%$} & Mean & 34,700 & 22,800 & 28,800 & 36,400 & 28,200 & 29,100 & 57,700 & 59,000 & 34,700 & 68,800 & 76,400 & 37,500 \\
\hline & & Median & 33,000 & 16,900 & 15,500 & 34,900 & 18,700 & 15,300 & 56,700 & 47,600 & 20,600 & 66,900 & 66,100 & 23,300 \\
\hline & \multirow{2}{*}{$2 \%$} & Mean & 34,600 & 24,400 & 28,900 & 36,000 & 28,400 & 29,300 & 56,500 & 55,400 & 25,100 & 67,200 & 70,500 & 38,100 \\
\hline & & Median & 33,200 & 16,200 & 14,700 & 34,000 & 18,500 & 14,700 & 55,500 & 45,500 & 20,000 & 65,600 & 62,000 & 22,600 \\
\hline
\end{tabular}

Table 8B: Average Annual Total Cost of Program (in millions of 2009 dollars)

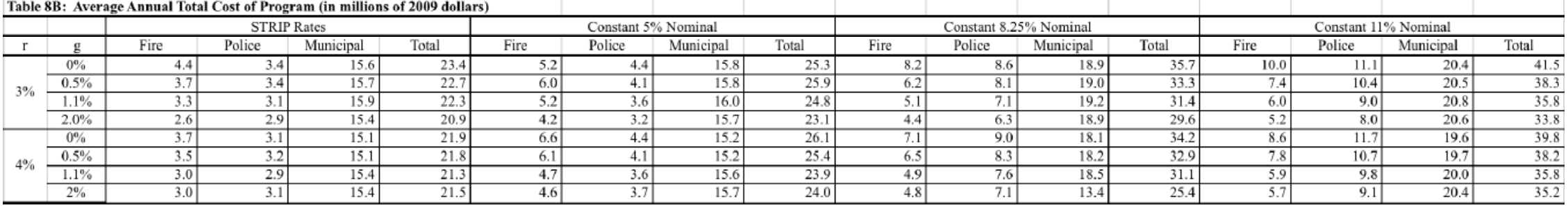


Table 9 A: Regression Results with Quality Indicator: Marginal Effects Estimates on Pension Variables (at sample mean) (r=3\%, $\mathrm{g}=1.1 \%)$

\begin{tabular}{|c|c|c|c|c|c|c|}
\hline \multirow[t]{2}{*}{ Dependent Variable: Voluntarily Leaves One's Job } & \multicolumn{3}{|c|}{ Full Sample } & \multicolumn{3}{|c|}{ Only Age 40+ } \\
\hline & Fire & Police & Municipal & Fire & Police & Municipal \\
\hline \multicolumn{7}{|l|}{ Pension wealth variables } \\
\hline Pension wealth/earnings & $\begin{array}{c}0.00442 * * * \\
(0.00126)\end{array}$ & $\begin{array}{r}-0.0000370 \\
(0.000440)\end{array}$ & $\begin{array}{c}0.000334 \\
(0.000384)\end{array}$ & $\begin{array}{c}0.00974 * * * \\
(0.00335)\end{array}$ & $\begin{array}{l}-0.000429 \\
(0.000924)\end{array}$ & $\begin{array}{c}0.000302 \\
(0.000367)\end{array}$ \\
\hline $\begin{array}{l}\text { Difference between current and peak } \\
\text { wealth/earnings }\end{array}$ & $\begin{array}{l}-0.00532 \\
(0.00468)\end{array}$ & $\begin{array}{c}-0.00990 * * * \\
(0.00195)\end{array}$ & $\begin{array}{c}-0.00710^{* * *} \\
(0.00129)\end{array}$ & $\begin{array}{l}-0.0144 \\
(0.0156)\end{array}$ & $\begin{array}{c}-0.0491 * * * \\
(0.00911)\end{array}$ & $\begin{array}{c}-0.00819 * * * \\
(0.00146)\end{array}$ \\
\hline $\begin{array}{l}\text { Squared difference between current and peak } \\
\text { wealth/earnings }\end{array}$ & $\begin{array}{c}0.000642 \\
(0.000475)\end{array}$ & $\begin{array}{l}0.000140^{* * *} \\
(0.0000294)\end{array}$ & $\begin{array}{l}0.000290 * * * \\
(0.0001000)\end{array}$ & $\begin{array}{l}-0.00111 \\
(0.00486)\end{array}$ & $\begin{array}{l}-0.000587 \\
(0.00264)\end{array}$ & $\begin{array}{r}0.000264 * * * \\
(0.0000790)\end{array}$ \\
\hline At early retirement wealth spike & $\begin{array}{c}0.0172 \\
(0.0163)\end{array}$ & $\begin{array}{c}0.00706 \\
(0.00982)\end{array}$ & $\begin{array}{l}-0.00630 \\
(0.00492)\end{array}$ & $\begin{array}{c}0.0415 \\
(0.0349)\end{array}$ & $\begin{array}{c}0.0714^{* * *} \\
(0.0231)\end{array}$ & $\begin{array}{l}-0.00732 \\
(0.00465)\end{array}$ \\
\hline At normal retirement age wealth spike & $\begin{array}{c}0.0332 * * \\
(0.0163)\end{array}$ & $\begin{array}{l}0.0361^{* * *} \\
(0.00752)\end{array}$ & $\begin{array}{l}0.0926^{* * *} \\
(0.00738)\end{array}$ & $\begin{array}{c}0.0757^{* *} \\
(0.0350)\end{array}$ & $\begin{array}{c}0.0464^{* * *} \\
(0.0128)\end{array}$ & $\begin{array}{l}0.0876^{* * *} \\
(0.00704)\end{array}$ \\
\hline After normal retirement age & $\begin{array}{c}0.0259 * * \\
(0.0102)\end{array}$ & $\begin{array}{c}0.0497^{* * *} \\
(0.0103)\end{array}$ & $\begin{array}{l}0.0624^{* * *} \\
(0.00870)\end{array}$ & $\begin{array}{c}0.0502^{* * *} \\
(0.0141)\end{array}$ & $\begin{array}{c}0.0708^{* * *} \\
(0.0119)\end{array}$ & $\begin{array}{l}0.0618^{* * *} \\
(0.00816)\end{array}$ \\
\hline Is Not Vested & $\begin{array}{l}0.0376 \\
(0.111)\end{array}$ & $\begin{array}{l}0.0470^{*} \\
(0.0270)\end{array}$ & $\begin{array}{c}0.00197 \\
(0.00613)\end{array}$ & $\begin{array}{l}-0.0270 \\
(0.0759)\end{array}$ & $\begin{array}{c}0.134 \\
(0.162)\end{array}$ & $\begin{array}{l}-0.0458^{* * *} \\
(0.0105)\end{array}$ \\
\hline \multicolumn{7}{|l|}{ Is Not Vested interacted with: } \\
\hline $\begin{array}{l}\text { Difference between current and peak } \\
\text { wealth/earnings }\end{array}$ & $\begin{array}{l}0.00370 \\
(0.0271)\end{array}$ & $\begin{array}{l}-0.00419 \\
(0.00367)\end{array}$ & $\begin{array}{c}0.00419 * * * \\
(0.00142)\end{array}$ & $\begin{array}{l}0.0633 \\
(0.108)\end{array}$ & $\begin{array}{c}-0.000226 \\
(0.0186)\end{array}$ & $\begin{array}{l}0.0272 * * * \\
(0.00660)\end{array}$ \\
\hline $\begin{array}{l}\text { Squared difference between current and peak } \\
\text { wealth/earnings }\end{array}$ & $\begin{array}{r}-0.000960 \\
(0.00320)\end{array}$ & $\begin{array}{l}0.000130 * * \\
(0.0000654)\end{array}$ & $\begin{array}{c}-0.000260 * * * \\
(0.0000971)\end{array}$ & $\begin{array}{l}-0.00785 \\
(0.0151)\end{array}$ & $\begin{array}{c}0.00344 \\
(0.00287)\end{array}$ & $\begin{array}{c}-0.00270^{* * *} \\
(0.000966)\end{array}$ \\
\hline At peak pension wealth & $\begin{array}{l}0.0203 * * \\
(0.00863)\end{array}$ & $\begin{array}{c}0.00560 \\
(0.00393)\end{array}$ & $\begin{array}{l}0.0460 * * * \\
(0.00600)\end{array}$ & $\begin{array}{l}0.0390 * * * \\
(0.0150)\end{array}$ & $\begin{array}{l}0.0220 * * \\
(0.00857)\end{array}$ & $\begin{array}{l}0.0397 * * * \\
(0.00563)\end{array}$ \\
\hline One to Four years past peak & $\begin{array}{l}0.0123 * * \\
(0.00492)\end{array}$ & $\begin{array}{c}0.0261^{* * *} \\
(0.00420)\end{array}$ & $\begin{array}{c}0.0895^{* * *} \\
(0.00828)\end{array}$ & $\begin{array}{l}0.0284^{* * *} \\
(0.00904)\end{array}$ & $\begin{array}{c}0.0479 * * * \\
(0.00694)\end{array}$ & $\begin{array}{l}0.0786 * * * \\
(0.00776)\end{array}$ \\
\hline Five or more years past peak & $\begin{array}{l}0.0177^{* *} \\
(0.00847)\end{array}$ & $\begin{array}{c}0.0153^{* * *} \\
(0.00550)\end{array}$ & $\begin{array}{c}0.0473^{* * *} \\
(0.0100)\end{array}$ & $\begin{array}{l}0.0442^{* * *} \\
(0.0168)\end{array}$ & $\begin{array}{c}0.0414^{* * *} \\
(0.0111)\end{array}$ & $\begin{array}{l}0.0385 * * * \\
(0.00916)\end{array}$ \\
\hline \multicolumn{7}{|l|}{ DROP eligibility interacted with: } \\
\hline Not yet attained peak pension wealth & $\begin{array}{c}0.00889 \\
(0.00850)\end{array}$ & $\begin{array}{c}0.00239 \\
(0.00266)\end{array}$ & $\begin{array}{c}-0.0106 * * * \\
(0.00202)\end{array}$ & $\begin{array}{c}-0.00610 \\
(0.0157)\end{array}$ & $\begin{array}{c}-0.0140 * * \\
(0.00584)\end{array}$ & $\begin{array}{c}-0.0150^{* * *} \\
(0.00181)\end{array}$ \\
\hline At peak pension wealth & $\begin{array}{c}-0.0113^{* * *} \\
(0.00175)\end{array}$ & $\begin{array}{l}-0.00418 \\
(0.00302)\end{array}$ & $\begin{array}{c}-0.0201 * * * \\
(0.00139)\end{array}$ & $\begin{array}{c}-0.0272 * * * \\
(0.00416)\end{array}$ & $\begin{array}{c}-0.0146 * * \\
(0.00641)\end{array}$ & $\begin{array}{c}-0.0224 * * * \\
(0.00130)\end{array}$ \\
\hline One to Four years past peak & $\begin{array}{l}-0.00557 \\
(0.00346)\end{array}$ & $\begin{array}{c}-0.00947^{* * *} \\
(0.00124)\end{array}$ & $\begin{array}{c}-0.0150^{* * *} \\
(0.00162)\end{array}$ & $\begin{array}{c}-0.0250 * * * \\
(0.00849)\end{array}$ & $\begin{array}{c}-0.0198^{* * *} \\
(0.00469)\end{array}$ & $\begin{array}{c}-0.0180^{* * *} \\
(0.00156)\end{array}$ \\
\hline Five or more years past peak & $\begin{array}{l}-0.00348 \\
(0.00423)\end{array}$ & $\begin{array}{r}-0.000792 \\
(0.00288)\end{array}$ & $\begin{array}{c}0.0102^{*} \\
(0.00612)\end{array}$ & $\begin{array}{l}-0.0180^{*} \\
(0.0100)\end{array}$ & $\begin{array}{c}-0.0129 * * \\
(0.00631)\end{array}$ & $\begin{array}{c}0.00893 \\
(0.00609)\end{array}$ \\
\hline \multicolumn{7}{|l|}{ High Quality Indicator interacted with: } \\
\hline Not yet attained peak pension wealth & $\begin{array}{c}0.00324 \\
(0.00226)\end{array}$ & $\begin{array}{c}0.0000574 \\
(0.00113)\end{array}$ & $\begin{array}{l}0.00230^{*} \\
(0.00124)\end{array}$ & $\begin{array}{c}0.00142 \\
(0.00630)\end{array}$ & $\begin{array}{c}-0.0174 * * * \\
(0.00297)\end{array}$ & $\begin{array}{c}0.00327 * * \\
(0.00165)\end{array}$ \\
\hline At peak pension wealth & $\begin{array}{c}0.0472 * * * \\
(0.0175)\end{array}$ & $\begin{array}{l}0.0224^{*} \\
(0.0115)\end{array}$ & $\begin{array}{c}0.00145 \\
(0.00454)\end{array}$ & $\begin{array}{c}0.126 * * * \\
(0.0356)\end{array}$ & $\begin{array}{c}-0.0132 \\
(0.00870)\end{array}$ & $\begin{array}{c}-0.0000877 \\
(0.00429)\end{array}$ \\
\hline One to Four years past peak & $\begin{array}{l}0.0160 * * \\
(0.00747)\end{array}$ & $\begin{array}{l}0.000751 \\
(0.00306)\end{array}$ & $\begin{array}{c}-0.0110^{* * *} \\
(0.00313)\end{array}$ & $\begin{array}{c}-0.00790 \\
(0.00798)\end{array}$ & $\begin{array}{l}-0.00612 \\
(0.00518)\end{array}$ & $\begin{array}{c}-0.0141^{* * *} \\
(0.00270)\end{array}$ \\
\hline Five or more years past peak & $\begin{array}{c}0.0267 \\
(0.0223)\end{array}$ & $\begin{array}{c}0.0109 \\
(0.0113)\end{array}$ & $\begin{array}{c}0.0410^{* *} \\
(0.0161)\end{array}$ & $\begin{array}{c}0.0165 \\
(0.0244)\end{array}$ & $\begin{array}{l}-0.0134^{*} \\
(0.00802)\end{array}$ & $\begin{array}{l}0.0286^{*} \\
(0.0160)\end{array}$ \\
\hline \multicolumn{7}{|l|}{ DROP eligibility \& High Quality interacted with: } \\
\hline Not yet attained peak pension wealth & $\begin{array}{l}-0.00518 \\
(0.00341)\end{array}$ & $\begin{array}{l}-0.00240 \\
(0.00207)\end{array}$ & $\begin{array}{l}-0.00154 \\
(0.00411)\end{array}$ & $\begin{array}{l}-0.00274 \\
(0.0122)\end{array}$ & $\begin{array}{c}0.0115 \\
(0.00920)\end{array}$ & $\begin{array}{l}-0.00234 \\
(0.00422)\end{array}$ \\
\hline At peak pension wealth & $\begin{array}{c}-0.00780^{* *} \\
(0.00343)\end{array}$ & $\begin{array}{c}-0.0000958 \\
(0.00653)\end{array}$ & $\begin{array}{l}-0.00788 \\
(0.00522)\end{array}$ & $\begin{array}{c}-0.0257 * * * \\
(0.00355)\end{array}$ & $\begin{array}{l}-0.00362 \\
(0.0137)\end{array}$ & $\begin{array}{c}-0.00323 \\
(0.00610)\end{array}$ \\
\hline One to Four years past peak & $\begin{array}{c}-0.00823^{* * *} \\
(0.00208)\end{array}$ & $\begin{array}{c}0.0340 * * * \\
(0.00995)\end{array}$ & $\begin{array}{l}0.0164 * * \\
(0.00781)\end{array}$ & $\begin{array}{c}0.0101 \\
(0.0155)\end{array}$ & $\begin{array}{c}0.00780 \\
(0.00926)\end{array}$ & $\begin{array}{l}0.0179 * * \\
(0.00803)\end{array}$ \\
\hline Five or more years past peak & $\begin{array}{l}0.00276 \\
(0.0115)\end{array}$ & $\begin{array}{c}0.0341 \\
(0.0298)\end{array}$ & $\begin{array}{c}-0.0139 * * \\
(0.00605)\end{array}$ & $\begin{array}{l}-0.0109 \\
(0.0128)\end{array}$ & $\begin{array}{c}0.0469 \\
(0.0329)\end{array}$ & $\begin{array}{c}-0.0191^{* * *} \\
(0.00482)\end{array}$ \\
\hline $\mathrm{N}$ & 26,269 & 87,739 & 170,141 & 16272 & 37842 & 117076 \\
\hline Log likelihood per observation & -0.13784 & -0.12664 & -0.16099 & -0.19931 & -0.22329 & -0.16985 \\
\hline \multicolumn{7}{|c|}{$\begin{array}{l}\text { Notes: Same samples as in Table 2. The tables report marginal effects from probits estimated using person-level analysis weights, computed at sample means of righthand side } \\
\text { variables; Huber-White standard errors in parentheses that have been adjusted for person-level clustering; and significance at } 90(*), 95(* *) \text {, and } 99(* * *) \text { percent levels. The } \\
\text { dependent variable is a dummy for leaving one’s job and retiring from one age to the next between } 1991 \text { and } 2008 \text {. The regression also includes dummies for age and year. }\end{array}$} \\
\hline Source: Authors' tabulation of administrative data. & & & & & & \\
\hline
\end{tabular}


Table 9 B: Regression Results with Quality Indicator: Marginal Effects Estimates on Non-Pension Variables (at sample mean) (r=3\%, $\mathrm{g}=1.1 \%)$

\begin{tabular}{|c|c|c|c|c|c|c|}
\hline Dependent Variable: Voluntarily Leaves One's Job & \multicolumn{3}{|c|}{ Full Sample } & \multicolumn{3}{|c|}{ Only Age $40+$} \\
\hline & Fire & Police & Municipal & Fire & Police & Municipal \\
\hline Female & $\begin{array}{c}0.0131 \\
(0.00914)\end{array}$ & $\begin{array}{c}0.00928 * * * \\
(0.00166)\end{array}$ & $\begin{array}{l}\text { 0.00193* } \\
(0.00110)\end{array}$ & $\begin{array}{c}0.0348 \\
(0.0347)\end{array}$ & $\begin{array}{c}0.0254^{* * *} \\
(0.00445)\end{array}$ & $\begin{array}{c}0.00272^{* *} \\
(0.00129)\end{array}$ \\
\hline Married & $\begin{array}{l}-0.000229 \\
(0.00134)\end{array}$ & $\begin{array}{c}0.000584 \\
(0.000765)\end{array}$ & $\begin{array}{l}-0.000800 \\
(0.000844)\end{array}$ & $\begin{array}{l}0.000189 \\
(0.00306)\end{array}$ & $\begin{array}{c}0.00257 \\
(0.00177)\end{array}$ & $\begin{array}{c}0.000493 \\
(0.000996)\end{array}$ \\
\hline Marital Status Unknown & $\begin{array}{c}0.00499 \\
(0.00525)\end{array}$ & $\begin{array}{c}0.00707^{* * *} \\
(0.00232)\end{array}$ & $\begin{array}{c}0.00522^{* * *} \\
(0.00189)\end{array}$ & $\begin{array}{c}0.0133 \\
(0.0127)\end{array}$ & $\begin{array}{l}0.0108^{* *} \\
(0.00480)\end{array}$ & $\begin{array}{c}0.00477^{* *} \\
(0.00218)\end{array}$ \\
\hline \multicolumn{7}{|l|}{ Education: } \\
\hline No data & $\begin{array}{c}0.00488 \\
(0.00459)\end{array}$ & $\begin{array}{c}-0.0111 * * * \\
(0.00165)\end{array}$ & $\begin{array}{l}-0.00131 \\
(0.00155)\end{array}$ & $\begin{array}{l}0.000598 \\
(0.00862)\end{array}$ & $\begin{array}{c}-0.0168^{* * *} \\
(0.00563)\end{array}$ & $\begin{array}{l}-0.00110 \\
(0.00200)\end{array}$ \\
\hline Less than high school & $\begin{array}{l}0.000751 \\
(0.00370)\end{array}$ & $\begin{array}{c}-0.00595 * * * \\
(0.00183)\end{array}$ & $\begin{array}{c}-0.00354^{* *} \\
(0.00179)\end{array}$ & $\begin{array}{l}-0.00104 \\
(0.00772)\end{array}$ & $\begin{array}{l}0.000364 \\
(0.00695)\end{array}$ & $\begin{array}{l}-0.00100 \\
(0.00233)\end{array}$ \\
\hline High School/GED & $\begin{array}{l}-0.00148 \\
(0.00319)\end{array}$ & $\begin{array}{c}-0.0111^{* * *} \\
(0.00182)\end{array}$ & $\begin{array}{c}-0.00693^{* * * *} \\
(0.00146)\end{array}$ & $\begin{array}{l}-0.00576 \\
(0.00715)\end{array}$ & $\begin{array}{c}-0.00971^{* *} \\
(0.00467)\end{array}$ & $\begin{array}{c}-0.00426^{* *} \\
(0.00191)\end{array}$ \\
\hline Some College - No Degree & $\begin{array}{c}-0.0000529 \\
(0.00330)\end{array}$ & $\begin{array}{c}-0.00629 * * * \\
(0.00168)\end{array}$ & $\begin{array}{c}-0.00511^{* * *} \\
(0.00155)\end{array}$ & $\begin{array}{l}-0.00370 \\
(0.00680)\end{array}$ & $\begin{array}{l}-0.00311 \\
(0.00544)\end{array}$ & $\begin{array}{l}-0.00389^{*} \\
(0.00202)\end{array}$ \\
\hline Some Postgrad - No Degree & $\begin{array}{c}-0.0115^{* * *} \\
(0.00117)\end{array}$ & $\begin{array}{l}0.00575 \\
(0.0104)\end{array}$ & $\begin{array}{l}-0.00184 \\
(0.00467)\end{array}$ & $\begin{array}{c}-0.0271^{* * *} \\
(0.00254)\end{array}$ & $\begin{array}{c}0.0374 \\
(0.0243)\end{array}$ & $\begin{array}{l}-0.00572 \\
(0.00414)\end{array}$ \\
\hline Masters Degree & $\begin{array}{l}-0.00467 \\
(0.00522)\end{array}$ & $\begin{array}{c}-0.0101^{* * *} \\
(0.00190)\end{array}$ & $\begin{array}{c}0.00945^{* * *} \\
(0.00257)\end{array}$ & $\begin{array}{l}-0.00807 \\
(0.0137)\end{array}$ & $\begin{array}{c}-0.0133^{* * *} \\
(0.00516)\end{array}$ & $\begin{array}{l}0.00553 * \\
(0.00294)\end{array}$ \\
\hline Doctoral Degree & -- & $\begin{array}{l}-0.0152 * * * \\
(0.000567)\end{array}$ & $\begin{array}{c}0.0503 * * * \\
(0.0102)\end{array}$ & -- & $\begin{array}{c}-0.0329 * * * \\
(0.00177)\end{array}$ & $\begin{array}{c}0.0162 * \\
(0.00967)\end{array}$ \\
\hline \multicolumn{7}{|l|}{ Occupation: } \\
\hline Pink Collar & -- & -- & $\begin{array}{c}-0.00663^{* * *} \\
(0.00111)\end{array}$ & -- & -- & $\begin{array}{c}-0.00882 * * * \\
(0.00131)\end{array}$ \\
\hline White Collar & -- & -- & $\begin{array}{l}-0.00218 * \\
(0.00131)\end{array}$ & -- & -- & $\begin{array}{c}-0.00487 * * * \\
(0.00154)\end{array}$ \\
\hline Managerial & $\begin{array}{c}-0.00853 * * * \\
(0.00144)\end{array}$ & $\begin{array}{l}-0.00118 \\
(0.00105)\end{array}$ & $\begin{array}{c}-0.00301^{* *} \\
(0.00125)\end{array}$ & $\begin{array}{c}-0.0152 * * * \\
(0.00393)\end{array}$ & $\begin{array}{l}-0.00206 \\
(0.00241)\end{array}$ & $\begin{array}{l}-0.00250^{*} \\
(0.00138)\end{array}$ \\
\hline \multicolumn{7}{|l|}{ Ethnicity: } \\
\hline White & $\begin{array}{c}-0.00411^{* *} \\
(0.00165)\end{array}$ & $\begin{array}{c}0.000648 \\
(0.000875)\end{array}$ & $\begin{array}{c}0.00132 \\
(0.000876)\end{array}$ & $\begin{array}{c}-0.00914^{* *} \\
(0.00381)\end{array}$ & $\begin{array}{l}-0.00298 \\
(0.00223)\end{array}$ & $\begin{array}{c}-0.00314 * * * \\
(0.00101)\end{array}$ \\
\hline Hispanic/Latino & $\begin{array}{l}-0.00579 * \\
(0.00313)\end{array}$ & $\begin{array}{l}-0.000346 \\
(0.00206)\end{array}$ & $\begin{array}{l}-0.00267 \\
(0.00227)\end{array}$ & $\begin{array}{l}-0.00726 \\
(0.0112)\end{array}$ & $\begin{array}{l}-0.00785 \\
(0.00502)\end{array}$ & $\begin{array}{l}-0.00376 \\
(0.00280)\end{array}$ \\
\hline Asian/Native American/Multiracia//Other & $\begin{array}{c}0.0310 \\
(0.0237)\end{array}$ & $\begin{array}{c}0.00799 \\
(0.00587)\end{array}$ & $\begin{array}{c}-0.00957 * * * \\
(0.00261)\end{array}$ & $\begin{array}{c}0.0984 \\
(0.0762)\end{array}$ & $\begin{array}{l}-0.00596 \\
(0.0117)\end{array}$ & $\begin{array}{c}-0.0137 * * * \\
(0.00283)\end{array}$ \\
\hline Unknown & -- & $\begin{array}{c}0.0464 \\
(0.0354)\end{array}$ & $\begin{array}{c}0.0740 * * * \\
(0.0200)\end{array}$ & -- & $\begin{array}{c}0.0331 \\
(0.0387)\end{array}$ & $\begin{array}{c}0.0815^{* *} \\
(0.0344)\end{array}$ \\
\hline Earnings (thousands of 2008 Dollars) & $\begin{array}{c}0.00310^{* * * *} \\
(0.000850)\end{array}$ & $\begin{array}{c}-0.000690^{* * *} \\
(0.000151)\end{array}$ & $\begin{array}{c}-0.00108^{* * *} \\
(0.000171)\end{array}$ & $\begin{array}{c}0.00547 * * * \\
(0.00209)\end{array}$ & $\begin{array}{c}-0.000741^{* *} \\
(0.000360)\end{array}$ & $\begin{array}{c}-0.00135^{* * *} \\
(0.000197)\end{array}$ \\
\hline Squared Earnings (thousands of 2008 Dollars) & $\begin{array}{c}-0.0000220^{* * *} \\
(0.00000609)\end{array}$ & $\begin{array}{c}0.00000270^{* * *} \\
(0.000000805)\end{array}$ & $\begin{array}{c}0.00000577^{* * *} \\
(0.00000164)\end{array}$ & $\begin{array}{c}-0.0000394 * * * \\
(0.0000148)\end{array}$ & $\begin{array}{l}0.00000373 * \\
(0.00000195)\end{array}$ & $\begin{array}{c}0.00000917^{* * *} \\
(0.00000183)\end{array}$ \\
\hline Years of Service & $\begin{array}{c}0.00197 \\
(0.00187)\end{array}$ & $\begin{array}{c}0.00655^{* * *} \\
(0.000995)\end{array}$ & $\begin{array}{c}0.00555^{* * *} \\
(0.000523)\end{array}$ & $\begin{array}{c}0.00322 \\
(0.00502)\end{array}$ & $\begin{array}{c}0.00658^{* *} \\
(0.00276)\end{array}$ & $\begin{array}{l}0.00155^{* *} \\
(0.000653)\end{array}$ \\
\hline Squared Years of Service & $\begin{array}{l}-0.0000476 \\
(0.0000760)\end{array}$ & $\begin{array}{c}-0.000190 * * * \\
(0.0000469)\end{array}$ & $\begin{array}{c}-0.000180 * * * \\
(0.0000263)\end{array}$ & $\begin{array}{r}-0.0000530 \\
(0.000191)\end{array}$ & $\begin{array}{l}-0.000128 \\
(0.000121)\end{array}$ & $\begin{array}{c}0.0000116 \\
(0.0000294)\end{array}$ \\
\hline Cubed Years of Service & $\begin{array}{l}0.000000518 \\
(0.00000102)\end{array}$ & $\begin{array}{c}0.00000243^{* * *} \\
(0.000000708)\end{array}$ & $\begin{array}{c}0.00000202^{* * *} \\
(0.000000413)\end{array}$ & $\begin{array}{c}5.84 \mathrm{e}-08 \\
(0.00000247)\end{array}$ & $\begin{array}{c}0.00000127 \\
(0.00000172)\end{array}$ & $\begin{array}{c}-0.000000674 \\
(0.000000418)\end{array}$ \\
\hline
\end{tabular}

Source: Authors' tabulation of adminis trative data. 
Table 10: Retirement Delay (in years) due to DROP by Quality of Employee ( $r=3 \%, g=1.1 \%)$

\begin{tabular}{|c|c|c|c|c|c|}
\hline Estimation Sample & & & Fire & Police & Municipal \\
\hline \multirow{6}{*}{ Full Sample } & \multirow{2}{*}{ All } & Mean & 0.988 & 0.328 & 1.297 \\
\hline & & Median & 0.728 & 0.230 & 1.292 \\
\hline & \multirow{2}{*}{ High Quality } & Mean & 2.087 & -0.232 & 1.297 \\
\hline & & Median & 2.239 & -0.103 & 1.175 \\
\hline & \multirow{2}{*}{ Average Quality } & Mean & 0.555 & 0.616 & 1.297 \\
\hline & & Median & 0.445 & 0.646 & 1.297 \\
\hline \multirow{6}{*}{ Only age 40 plus } & \multirow{2}{*}{ All } & Mean & 1.840 & 1.170 & 1.590 \\
\hline & & Median & 1.605 & 1.138 & 1.603 \\
\hline & \multirow{2}{*}{ High Quality } & Mean & 2.825 & 0.728 & 1.629 \\
\hline & & Median & 2.834 & 0.826 & 1.501 \\
\hline & \multirow{2}{*}{ Average Quality } & Mean & 1.671 & 1.262 & 1.581 \\
\hline & & Median & 1.532 & 1.242 & 1.604 \\
\hline
\end{tabular}

Figure 1: Pension Wealth Accrual for Plan 87 employees

Male born in 1970 commencing employment in 2000 at $\$ 40,000$ starting salary

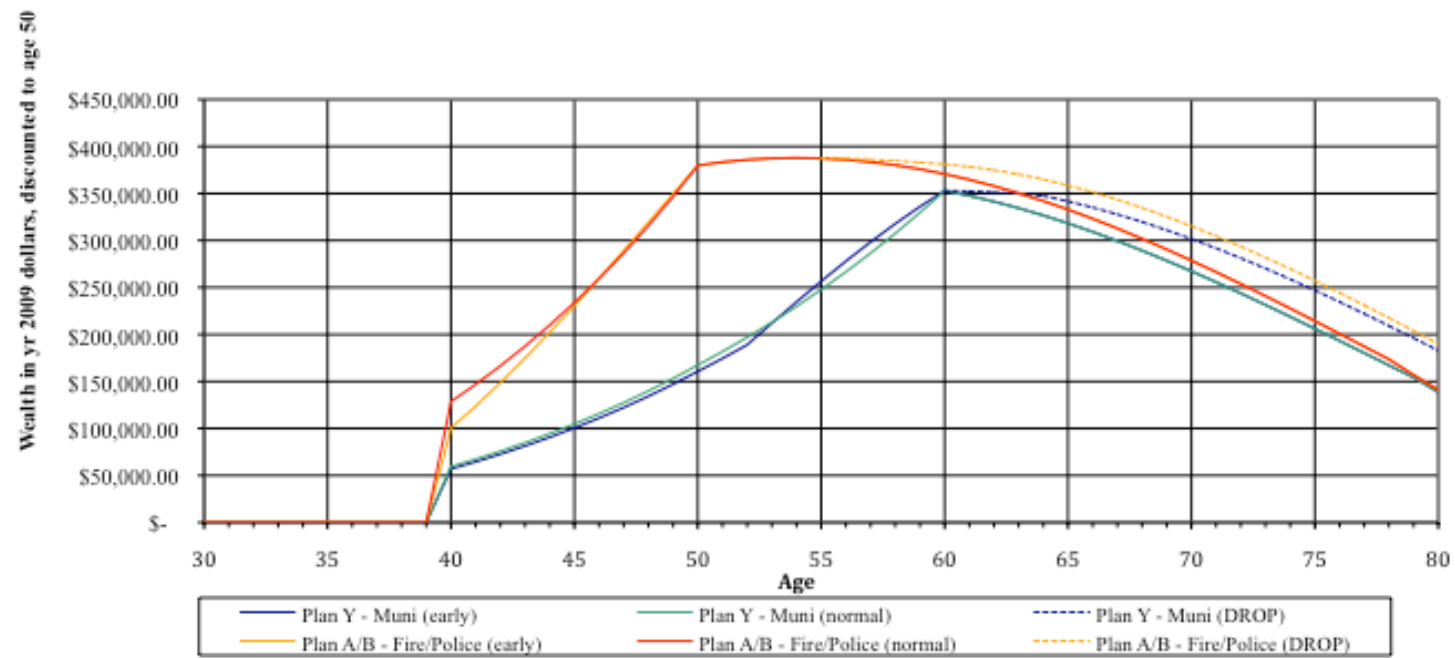


Figure 2: Cumulative Hazard Profile at age 54 of Fire Employee with peak at age 54

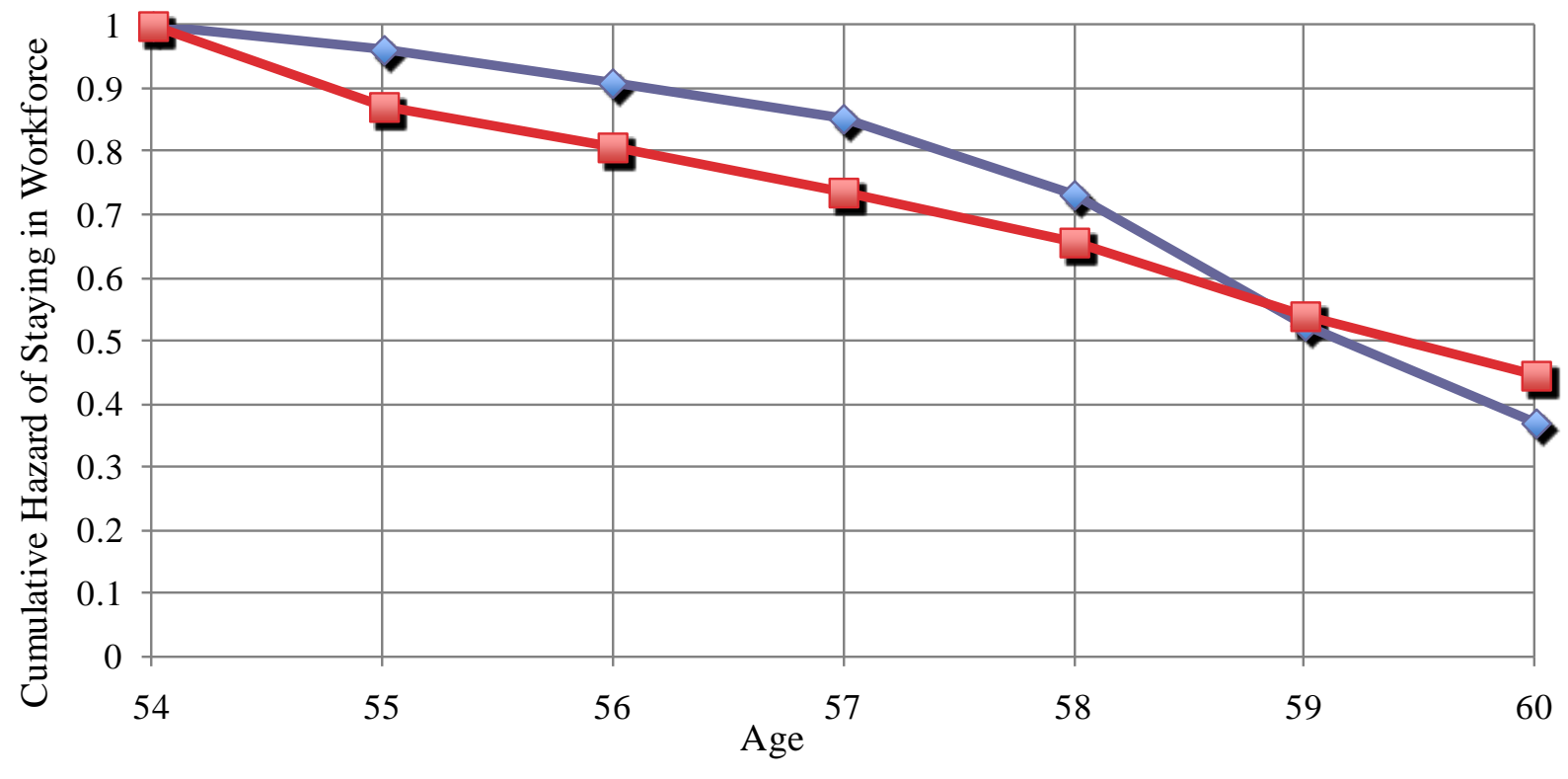

$\approx$-With DROP $\quad \square-$ Without DROP

Figure 3: Cumulative Hazard Profile at age 60 of Municipal Employee with peak at age 60

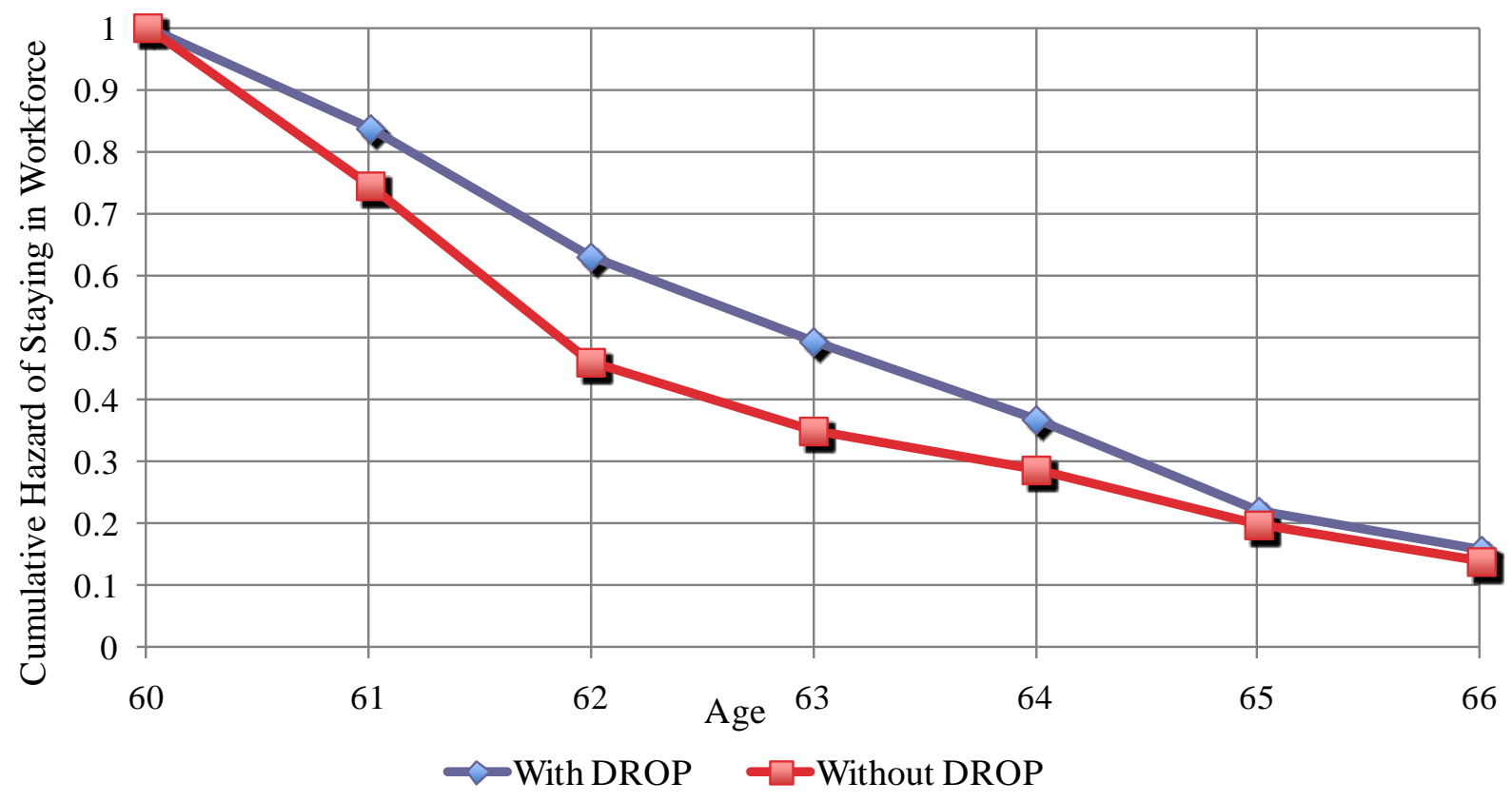




\section{Appendix}

\section{Cost Calculation}

In the following paragraphs, we provide a more detailed description of the methodology used to calculate the costs reported in Tables 8A and 8B.

For each DROP participant, we use the retirement model to obtain an estimate of the year and month the employee would have retired, had the DROP program not been available.

Given the employment history of the worker, we compute the monthly pension benefit payable by the city, and then discount this stream of payments to the year and month of actual retirement from DROP, using the prevailing monthly Treasury STRIP rates.

We construct two streams of payments, the actual stream, and the counterfactual stream, i.e., the stream of payments the city would have had to make had the DROP program not been in effect.

Both streams of payment begin in the year and month of first eligibility for DROP. The actual stream of payments consists of:

1) The monthly pension contributions by the employee until entry into the DROP, which is a credit for the city.

2) The lump-sum payment, which is the total of the accrued monthly pension benefits payable and the monthly compounded interest on these benefits, a debit for the city that is realized only at the date of exit from the DROP, which coincides with actual retirement.

3) The actual monthly pension benefit payments after exit from the DROP. The actual monthly pension benefit is calculated at the date of entry into the DROP. 
The counterfactual stream of payments consists of:

1) The predicted monthly contributions by the employee until the predicted retirement date, a credit for the city.

2) The predicted monthly pension benefit payments after predicted retirement. The predicted monthly pension benefit is calculated at the date of predicted retirement. If the predicted date of retirement is later than the actual date of retirement, earnings during the unobserved period are forecast using the assumed rates of inflation and real wage growth.

The cost to the city due to the DROP being used by our particular employee is the difference between the actual stream of payments and the counterfactual stream of payments, suitably discounted. We consider that the appropriate discount rate to use is the term structure based on Treasury STRIP rates. This term structure changes over time. We discount the difference in the payment streams to date of predicted retirement, using Treasury STRIP rates prevailing at that date. We further assume that the employee has population average mortality for individuals in the appropriate birth cohort. We test the sensitivity of our calculations to alternative discount rate assumptions. We convert the cost to 2009 dollars using the Consumer Price Index.

This method of computing the cost for a DROP-eligible employee who used the DROP can also be used to compute the cost for a DROP-eligible employee who did not use the DROP. The only difference is in the computation of the actual stream of payments and the actual monthly pension benefit. The actual stream of payments consists of:

1) The monthly contributions by the employee until actual retirement from service, a credit for the city.

2) The actual monthly pension benefit payments after retirement. The actual monthly pension benefit is calculated at the date of actual retirement.

With the cost computed for every DROP-eligible employee, we sum up the cost over all DROP-eligible employees and then divide by the number of DROP-eligible employees who used the DROP to obtain the average cost per DROP retiree. Finally, we report the 
total cost by multiplying the average cost per DROP retiree by the number of DROP retirees. 
Table 4C: Regression Results - Marginal Effects Estimates on Age and Year Dummies (at sample mean) (r=3\%, $\mathrm{g}=1.1 \%)$

$\underline{\text { Dependent Variable: Voluntarily Leaves One's Job }}$

\begin{tabular}{|c|c|c|c|c|c|}
\hline & All & Fire & Police & Municipal & Pre-1988 Pension Plan \\
\hline \multicolumn{6}{|l|}{ Year dummies } \\
\hline 1991 & $\begin{array}{c}0.0855 \\
(0.0185)\end{array}$ & $\begin{array}{l}-0.00942 \\
(0.00512)\end{array}$ & $\begin{array}{c}-0.00385 \\
(0.00643)\end{array}$ & $\begin{array}{c}0.187 \\
(0.0353)\end{array}$ & $\begin{array}{c}-0.0545 \\
(0.00428)\end{array}$ \\
\hline 1992 & $\begin{array}{c}0.229 \\
(0.0422)\end{array}$ & $\begin{array}{r}-0.00312 \\
(0.0131)\end{array}$ & $\begin{array}{c}0.0102 \\
(0.0162)\end{array}$ & $\begin{array}{c}0.428 \\
(0.0647)\end{array}$ & $\begin{array}{c}-0.0513 \\
(0.00644)\end{array}$ \\
\hline 1993 & $\begin{array}{c}0.0915 \\
(0.0183)\end{array}$ & $\begin{array}{c}-0.0121 \\
(0.00297)\end{array}$ & $\begin{array}{l}0.000756 \\
(0.00786)\end{array}$ & $\begin{array}{c}0.202 \\
(0.0350)\end{array}$ & $\begin{array}{c}-0.0503 \\
(0.00435)\end{array}$ \\
\hline 1994 & $\begin{array}{c}0.0302 \\
(0.00683)\end{array}$ & $\begin{array}{c}-0.0130 \\
(0.00183)\end{array}$ & $\begin{array}{l}-0.00652 \\
(0.00326)\end{array}$ & $\begin{array}{c}0.0830 \\
(0.0141)\end{array}$ & $\begin{array}{c}-0.0469 \\
(0.00306)\end{array}$ \\
\hline 1995 & $\begin{array}{c}0.0150 \\
(0.00395)\end{array}$ & $\begin{array}{c}-0.0108 \\
(0.00222)\end{array}$ & $\begin{array}{r}-0.00597 \\
(0.00252)\end{array}$ & $\begin{array}{c}0.0409 \\
(0.0074)\end{array}$ & $\begin{array}{c}-0.0432 \\
(0.00251)\end{array}$ \\
\hline 1996 & $\begin{array}{c}0.00749 \\
(0.00228)\end{array}$ & $\begin{array}{l}-0.00890 \\
(0.00239)\end{array}$ & $\begin{array}{r}-0.000568 \\
(0.00242)\end{array}$ & $\begin{array}{c}0.0134 \\
(0.00355)\end{array}$ & $\begin{array}{c}-0.0357 \\
(0.00216)\end{array}$ \\
\hline 1997 & $\begin{array}{l}-0.00978 \\
(0.00123)\end{array}$ & $\begin{array}{c}-0.0118 \\
(0.00164)\end{array}$ & $\begin{array}{r}-0.00668 \\
(0.0016)\end{array}$ & $\begin{array}{c}-0.00984 \\
(0.00179)\end{array}$ & $\begin{array}{c}-0.0350 \\
(0.0018)\end{array}$ \\
\hline 1998 & $\begin{array}{c}-0.0176 \\
(0.00137)\end{array}$ & $\begin{array}{c}-0.0111 \\
(0.00237)\end{array}$ & $\begin{array}{l}-0.00433 \\
(0.00289)\end{array}$ & $\begin{array}{c}-0.0234 \\
(0.00161)\end{array}$ & $\begin{array}{c}-0.0279 \\
(0.00371)\end{array}$ \\
\hline 1999 & $\begin{array}{c}-0.0168 \\
(0.00153)\end{array}$ & $\begin{array}{c}-0.00843 \\
(0.00294)\end{array}$ & $\begin{array}{c}-0.00522 \\
(0.00284)\end{array}$ & $\begin{array}{c}-0.0219 \\
(0.00187)\end{array}$ & $\begin{array}{c}-0.00898 \\
(0.00582)\end{array}$ \\
\hline 2000 & $\begin{array}{c}-0.0235 \\
(0.00114)\end{array}$ & $\begin{array}{c}-0.0113 \\
(0.00236)\end{array}$ & $\begin{array}{c}-0.0108 \\
(0.00214)\end{array}$ & $\begin{array}{c}-0.0283 \\
(0.00147)\end{array}$ & $\begin{array}{r}-0.0273 \\
(0.0047)\end{array}$ \\
\hline 2001 & $\begin{array}{c}-0.0211 \\
(0.00102)\end{array}$ & $\begin{array}{c}-0.0137 \\
(0.00154)\end{array}$ & $\begin{array}{c}-0.0133 \\
(0.00124)\end{array}$ & $\begin{array}{c}-0.0230 \\
(0.00152)\end{array}$ & $\begin{array}{c}-0.0361 \\
(0.00246)\end{array}$ \\
\hline 2002 & $\begin{array}{r}-0.00466 \\
(0.00198)\end{array}$ & $\begin{array}{c}-0.0141 \\
(0.00134)\end{array}$ & $\begin{array}{c}-0.0118 \\
(0.00126)\end{array}$ & $\begin{array}{c}0.00907 \\
(0.00374)\end{array}$ & $\begin{array}{c}-0.0441 \\
(0.00147)\end{array}$ \\
\hline 2003 & $\begin{array}{r}-0.000312 \\
(0.00215)\end{array}$ & $\begin{array}{c}-0.0109 \\
(0.00171)\end{array}$ & $\begin{array}{l}-0.00653 \\
(0.00183)\end{array}$ & $\begin{array}{c}0.0123 \\
(0.00384)\end{array}$ & $\begin{array}{c}-0.0369 \\
(0.00201)\end{array}$ \\
\hline 2004 & $\begin{array}{c}0.0150 \\
(0.00200)\end{array}$ & $\begin{array}{c}0.00607 \\
(0.00376)\end{array}$ & $\begin{array}{c}0.00212 \\
(0.00208)\end{array}$ & $\begin{array}{c}0.0213 \\
(0.00299)\end{array}$ & $\begin{array}{r}-0.00109 \\
(0.00335)\end{array}$ \\
\hline 2006 & $\begin{array}{r}-0.00320 \\
(0.00172)\end{array}$ & $\begin{array}{c}0.00203 \\
(0.00449)\end{array}$ & $\begin{array}{c}0.00580 \\
(0.00319)\end{array}$ & $\begin{array}{l}-0.00914 \\
(0.00205)\end{array}$ & $\begin{array}{c}0.0226 \\
(0.00583)\end{array}$ \\
\hline 2007 & $\begin{array}{r}-0.000467 \\
(0.00229)\end{array}$ & $\begin{array}{c}0.0162 \\
(0.00878)\end{array}$ & $\begin{array}{c}0.00967 \\
(0.00449)\end{array}$ & $\begin{array}{l}-0.00802 \\
(0.00259)\end{array}$ & $\begin{array}{c}0.103 \\
(0.0125)\end{array}$ \\
\hline \multicolumn{6}{|l|}{ Age dummies } \\
\hline Age 23 & - & - & $\begin{array}{c}0.0938 \\
(0.0453)\end{array}$ & $\begin{array}{c}0.0109 \\
(0.00858)\end{array}$ & -- \\
\hline Age 24 & $\begin{array}{c}0.0315 \\
(0.0074)\end{array}$ & $\begin{array}{c}0.0942 \\
(0.0867)\end{array}$ & $\begin{array}{c}0.189 \\
(0.0534)\end{array}$ & $\begin{array}{c}0.0275 \\
(0.00878)\end{array}$ & $\begin{array}{c}0.0109 \\
(0.0234)\end{array}$ \\
\hline Age 25 & $\begin{array}{c}0.0266 \\
(0.00645)\end{array}$ & $\begin{array}{c}0.0374 \\
(0.0527)\end{array}$ & $\begin{array}{c}0.125 \\
(0.0412)\end{array}$ & $\begin{array}{c}0.0311 \\
(0.00829)\end{array}$ & $\begin{array}{c}0.0355 \\
(0.0225)\end{array}$ \\
\hline Age 26 & $\begin{array}{c}0.0280 \\
(0.00617)\end{array}$ & $\begin{array}{c}0.0829 \\
(0.0639)\end{array}$ & $\begin{array}{c}0.143 \\
(0.0399)\end{array}$ & $\begin{array}{c}0.0257 \\
(0.00742)\end{array}$ & $\begin{array}{c}0.0282 \\
(0.0192)\end{array}$ \\
\hline Age 27 & $\begin{array}{c}0.0336 \\
(0.00624)\end{array}$ & $\begin{array}{l}0.0359 \\
(0.042)\end{array}$ & $\begin{array}{c}0.128 \\
(0.0365)\end{array}$ & $\begin{array}{c}0.0381 \\
(0.00795)\end{array}$ & $\begin{array}{c}0.0554 \\
(0.0198)\end{array}$ \\
\hline Age 28 & $\begin{array}{c}0.0264 \\
(0.00558)\end{array}$ & $\begin{array}{l}0.0598 \\
(0.045)\end{array}$ & $\begin{array}{c}0.106 \\
(0.0317)\end{array}$ & $\begin{array}{l}0.0279 \\
(0.007)\end{array}$ & $\begin{array}{c}0.0736 \\
(0.0193)\end{array}$ \\
\hline Age 29 & $\begin{array}{c}0.0295 \\
(0.0056)\end{array}$ & $\begin{array}{c}0.043 \\
(0.0365)\end{array}$ & $\begin{array}{c}0.125 \\
(0.0329)\end{array}$ & $\begin{array}{c}0.0274 \\
(0.00674)\end{array}$ & $\begin{array}{c}0.0419 \\
(0.0154)\end{array}$ \\
\hline Age 30 & $\begin{array}{c}0.0308 \\
(0.00550)\end{array}$ & $\begin{array}{l}0.0206 \\
(0.025)\end{array}$ & $\begin{array}{c}0.119 \\
(0.031)\end{array}$ & $\begin{array}{c}0.0302 \\
(0.00668)\end{array}$ & $\begin{array}{l}0.0664 \\
(0.016)\end{array}$ \\
\hline Age 31 & $\begin{array}{c}0.0185 \\
(0.00468)\end{array}$ & $\begin{array}{l}0.0373 \\
(0.031)\end{array}$ & $\begin{array}{c}0.0967 \\
(0.0268)\end{array}$ & $\begin{array}{c}0.0139 \\
(0.00547)\end{array}$ & $\begin{array}{l}0.0488 \\
(0.014)\end{array}$ \\
\hline Age 32 & $\begin{array}{c}0.0206 \\
(0.00467)\end{array}$ & $\begin{array}{c}0.0429 \\
(0.0315)\end{array}$ & $\begin{array}{c}0.0760 \\
(0.0228)\end{array}$ & $\begin{array}{c}0.0194 \\
(0.00567)\end{array}$ & $\begin{array}{c}0.0480 \\
(0.0133)\end{array}$ \\
\hline Age 33 & $\begin{array}{c}0.0150 \\
(0.00427)\end{array}$ & $\begin{array}{c}0.0177 \\
(0.0199)\end{array}$ & $\begin{array}{c}0.0665 \\
(0.0206)\end{array}$ & $\begin{array}{c}0.0134 \\
(0.00519)\end{array}$ & $\begin{array}{c}0.0388 \\
(0.0122)\end{array}$ \\
\hline Age 34 & $\begin{array}{c}0.0131 \\
(0.00404)\end{array}$ & $\begin{array}{l}0.00746 \\
(0.0138)\end{array}$ & $\begin{array}{c}0.0727 \\
(0.0204)\end{array}$ & $\begin{array}{c}0.00925 \\
(0.00476)\end{array}$ & $\begin{array}{c}0.0450 \\
(0.0119)\end{array}$ \\
\hline Age 35 & $\begin{array}{c}0.0113 \\
(0.00383)\end{array}$ & $\begin{array}{r}-0.00836 \\
(0.00586)\end{array}$ & $\begin{array}{c}0.0496 \\
(0.0164)\end{array}$ & $\begin{array}{c}0.0111 \\
(0.00474)\end{array}$ & $\begin{array}{c}0.0344 \\
(0.0106)\end{array}$ \\
\hline Age 36 & $\begin{array}{c}0.0125 \\
(0.00384)\end{array}$ & $\begin{array}{r}-0.00925 \\
(0.00489)\end{array}$ & $\begin{array}{c}0.0624 \\
(0.0171)\end{array}$ & $\begin{array}{c}0.00918 \\
(0.00455)\end{array}$ & $\begin{array}{c}0.0339 \\
(0.0102)\end{array}$ \\
\hline Age 37 & $\begin{array}{c}0.0148 \\
(0.00387)\end{array}$ & $\begin{array}{c}0.0258 \\
(0.0172)\end{array}$ & $\begin{array}{c}0.0467 \\
(0.0143)\end{array}$ & $\begin{array}{c}0.0122 \\
(0.00464)\end{array}$ & $\begin{array}{c}0.0314 \\
(0.00952)\end{array}$ \\
\hline Age 38 & $\begin{array}{c}0.00746 \\
(0.00342)\end{array}$ & $\begin{array}{c}-0.000705 \\
(0.00866)\end{array}$ & $\begin{array}{c}0.0391 \\
(0.0126)\end{array}$ & $\begin{array}{c}0.00441 \\
(0.00409)\end{array}$ & $\begin{array}{c}0.0242 \\
(0.00873)\end{array}$ \\
\hline Age 39 & $\begin{array}{c}0.0027 \\
(0.00308)\end{array}$ & $\begin{array}{c}0.00213 \\
(0.00919)\end{array}$ & $\begin{array}{c}0.0146 \\
(0.00834)\end{array}$ & $\begin{array}{c}0.00223 \\
(0.00389)\end{array}$ & $\begin{array}{c}0.0150 \\
(0.00774)\end{array}$ \\
\hline Age 40 & $\begin{array}{c}0.00328 \\
(0.00317)\end{array}$ & $\begin{array}{r}-0.00575 \\
(0.0057)\end{array}$ & $\begin{array}{c}0.0149 \\
(0.0138)\end{array}$ & $\begin{array}{r}-0.000427 \\
(0.00367)\end{array}$ & $\begin{array}{c}0.00701 \\
(0.00722)\end{array}$ \\
\hline
\end{tabular}




\begin{tabular}{|c|c|c|c|c|c|}
\hline Age 41 & $\begin{array}{l}-0.000339 \\
(0.00279)\end{array}$ & $\begin{array}{l}-0.00487 \\
(0.0057)\end{array}$ & $\begin{array}{c}0.00778 \\
(0.00607)\end{array}$ & $\begin{array}{r}-0.00127 \\
(0.00354)\end{array}$ & $\begin{array}{c}0.00122 \\
(0.00628)\end{array}$ \\
\hline Age 43 & $\begin{array}{r}-0.00383 \\
(0.00248)\end{array}$ & $\begin{array}{c}0.00252 \\
(0.00715)\end{array}$ & $\begin{array}{c}-0.00133 \\
(0.00392)\end{array}$ & $\begin{array}{r}-0.00683 \\
(0.00307)\end{array}$ & $\begin{array}{l}-0.00464 \\
(0.00544)\end{array}$ \\
\hline Age 44 & $\begin{array}{r}-0.00514 \\
(0.00234)\end{array}$ & $\begin{array}{r}-0.00747 \\
(0.00391)\end{array}$ & $\begin{array}{c}-0.00776 \\
(0.00283)\end{array}$ & $\begin{array}{l}-0.00469 \\
(0.00316)\end{array}$ & $\begin{array}{l}-0.00771 \\
(0.00509)\end{array}$ \\
\hline Age 45 & $\begin{array}{r}-0.000674 \\
(0.00243)\end{array}$ & $\begin{array}{c}-0.00551 \\
(0.00483)\end{array}$ & $\begin{array}{c}0.0151 \\
(0.00737)\end{array}$ & $\begin{array}{c}-0.00969 \\
(0.00279)\end{array}$ & $\begin{array}{r}-0.00439 \\
(0.00500)\end{array}$ \\
\hline Age 46 & $\begin{array}{c}-0.00576 \\
(0.00213)\end{array}$ & $\begin{array}{r}-0.00833 \\
(0.00429)\end{array}$ & $\begin{array}{c}-0.00732 \\
(0.00329)\end{array}$ & $\begin{array}{c}-0.0102 \\
(0.00274)\end{array}$ & $\begin{array}{r}-0.00416 \\
(0.00500)\end{array}$ \\
\hline Age 47 & $\begin{array}{c}-0.0117 \\
(0.00173)\end{array}$ & $\begin{array}{c}-0.0108 \\
(0.00281)\end{array}$ & $\begin{array}{c}-0.0108 \\
(0.00222)\end{array}$ & $\begin{array}{c}-0.0135 \\
(0.00251)\end{array}$ & $\begin{array}{c}-0.0175 \\
(0.00401)\end{array}$ \\
\hline Age 48 & $\begin{array}{c}-0.0131 \\
(0.00162)\end{array}$ & $\begin{array}{c}-0.0115 \\
(0.00243)\end{array}$ & $\begin{array}{c}-0.0111 \\
(0.00213)\end{array}$ & $\begin{array}{c}-0.0160 \\
(0.00232)\end{array}$ & $\begin{array}{c}-0.0198 \\
(0.0038)\end{array}$ \\
\hline Age 49 & $\begin{array}{c}-0.0133 \\
(0.00158)\end{array}$ & $\begin{array}{c}-0.0102 \\
(0.00313)\end{array}$ & $\begin{array}{c}-0.0112 \\
(0.00207)\end{array}$ & $\begin{array}{c}-0.0183 \\
(0.00213)\end{array}$ & $\begin{array}{c}-0.0202 \\
(0.00372)\end{array}$ \\
\hline Age 50 & $\begin{array}{c}-0.0159 \\
(0.00140)\end{array}$ & $\begin{array}{c}-0.0121 \\
(0.00207)\end{array}$ & $\begin{array}{c}-0.0118 \\
(0.00186)\end{array}$ & $\begin{array}{c}-0.0189 \\
(0.00211)\end{array}$ & $\begin{array}{c}-0.0238 \\
(0.00346)\end{array}$ \\
\hline Age 51 & $\begin{array}{c}-0.0193 \\
(0.00115)\end{array}$ & $\begin{array}{c}-0.0126 \\
(0.00188)\end{array}$ & $\begin{array}{c}-0.0138 \\
(0.00117)\end{array}$ & $\begin{array}{c}-0.0215 \\
(0.0019)\end{array}$ & $\begin{array}{c}-0.0300 \\
(0.00297)\end{array}$ \\
\hline Age 52 & $\begin{array}{c}-0.0179 \\
(0.00135)\end{array}$ & $\begin{array}{c}-0.0127 \\
(0.00176)\end{array}$ & $\begin{array}{c}-0.0133 \\
(0.00133)\end{array}$ & $\begin{array}{c}-0.0157 \\
(0.00346)\end{array}$ & $\begin{array}{c}-0.0263 \\
(0.00353)\end{array}$ \\
\hline Age 53 & $\begin{array}{c}-0.0185 \\
(0.00122)\end{array}$ & $\begin{array}{c}-0.0118 \\
(0.00221)\end{array}$ & $\begin{array}{c}-0.0136 \\
(0.00119)\end{array}$ & $\begin{array}{c}-0.0208 \\
(0.00205)\end{array}$ & $\begin{array}{c}-0.0274 \\
(0.00323)\end{array}$ \\
\hline Age 54 & $\begin{array}{c}-0.0200 \\
(0.00111)\end{array}$ & $\begin{array}{c}-0.0119 \\
(0.00207)\end{array}$ & $\begin{array}{c}-0.0138 \\
(0.0011)\end{array}$ & $\begin{array}{c}-0.0230 \\
(0.00189)\end{array}$ & $\begin{array}{c}-0.0319 \\
(0.00284)\end{array}$ \\
\hline Age 55 & $\begin{array}{c}=0.0114 \\
(0.00183)\end{array}$ & $\begin{array}{c}-0.0117 \\
(0.00218)\end{array}$ & $\begin{array}{c}-0.0121 \\
(0.00171)\end{array}$ & $\begin{array}{l}-0.00177 \\
(0.0042)\end{array}$ & $\begin{array}{r}-0.00986 \\
(0.00489)\end{array}$ \\
\hline Age 56 & $\begin{array}{c}-0.0212 \\
(0.000991)\end{array}$ & $\begin{array}{c}-0.0113 \\
(0.00235)\end{array}$ & $\begin{array}{c}-0.0132 \\
(0.00131)\end{array}$ & $\begin{array}{c}-0.0224 \\
(0.00216)\end{array}$ & $\begin{array}{c}-0.0276 \\
(0.00334)\end{array}$ \\
\hline Age 57 & $\begin{array}{c}-0.0221 \\
(0.000915)\end{array}$ & $\begin{array}{c}-0.0106 \\
(0.00272)\end{array}$ & $\begin{array}{c}-0.0124 \\
(0.00159)\end{array}$ & $\begin{array}{c}-0.0252 \\
(0.00176)\end{array}$ & $\begin{array}{c}-0.0308 \\
(0.00305)\end{array}$ \\
\hline Age 58 & $\begin{array}{c}-0.0234 \\
(0.000792)\end{array}$ & $\begin{array}{c}-0.0109 \\
(0.00251)\end{array}$ & $\begin{array}{c}-0.0123 \\
(0.00163)\end{array}$ & $\begin{array}{c}-0.0266 \\
(0.00154)\end{array}$ & $\begin{array}{c}-0.0344 \\
(0.00268)\end{array}$ \\
\hline Age 59 & $\begin{array}{c}-0.0141 \\
(0.00171)\end{array}$ & $\begin{array}{l}-0.00848 \\
(0.00416)\end{array}$ & $\begin{array}{c}-0.0121 \\
(0.00175)\end{array}$ & $\begin{array}{r}-0.00834 \\
(0.00406)\end{array}$ & $\begin{array}{c}-0.0102 \\
(0.00518)\end{array}$ \\
\hline Age 60 & $\begin{array}{c}-0.0178 \\
(0.00140)\end{array}$ & $\begin{array}{c}-0.0052 \\
(0.00658)\end{array}$ & $\begin{array}{l}-0.00945 \\
(0.00287)\end{array}$ & $\begin{array}{c}-0.0175 \\
(0.00287)\end{array}$ & $\begin{array}{c}-0.0169 \\
(0.00462)\end{array}$ \\
\hline Age 61 & $\begin{array}{c}-0.0189 \\
(0.00131)\end{array}$ & $\begin{array}{r}-0.00638 \\
(0.00596)\end{array}$ & $\begin{array}{c}-0.0117 \\
(0.00204)\end{array}$ & $\begin{array}{c}-0.0166 \\
(0.00312)\end{array}$ & $\begin{array}{c}-0.0162 \\
(0.00485)\end{array}$ \\
\hline Age 62 & $\begin{array}{r}-0.00550 \\
(0.00281)\end{array}$ & $\begin{array}{c}-0.00341 \\
(0.00849)\end{array}$ & $\begin{array}{c}-0.00999 \\
(0.00294)\end{array}$ & $\begin{array}{c}0.00790 \\
(0.00665)\end{array}$ & $\begin{array}{c}0.0255 \\
(0.00907)\end{array}$ \\
\hline Age 63 & $\begin{array}{c}-0.0143 \\
(0.00197)\end{array}$ & $\begin{array}{l}-0.00419 \\
(0.0081)\end{array}$ & $\begin{array}{c}-0.0115 \\
(0.00237)\end{array}$ & $\begin{array}{l}-0.00818 \\
(0.00455)\end{array}$ & $\begin{array}{c}0.00169 \\
(0.00711)\end{array}$ \\
\hline Age 64 & $\begin{array}{c}-0.0175 \\
(0.00167)\end{array}$ & $\begin{array}{c}0.000991 \\
(0.0139)\end{array}$ & $\begin{array}{c}-0.00944 \\
(0.00355)\end{array}$ & $\begin{array}{c}-0.0148 \\
(0.00362)\end{array}$ & $\begin{array}{c}-0.00757 \\
(0.00637)\end{array}$ \\
\hline Age 65 & - & - & $\begin{array}{c}-0.0115 \\
(0.00299)\end{array}$ & $\begin{array}{c}0.0130 \\
(0.00784)\end{array}$ & - \\
\hline Age $65+$ & $\begin{array}{c}-0.0143 \\
(0.00203)\end{array}$ & $\begin{array}{l}-0.00333 \\
(0.0106)\end{array}$ & - & - & $\begin{array}{c}0.00539 \\
(0.00739)\end{array}$ \\
\hline Age 66 & - & - & $\begin{array}{c}-0.0131 \\
(0.00233)\end{array}$ & $\begin{array}{l}-0.00653 \\
(0.0054)\end{array}$ & -- \\
\hline Age 67 & - & - & $\begin{array}{r}-0.00779 \\
(0.00454)\end{array}$ & $\begin{array}{c}-0.0138 \\
(0.00437)\end{array}$ & - \\
\hline Age 68 & - & - & $\begin{array}{c}-0.0111 \\
(0.00618)\end{array}$ & $\begin{array}{c}-0.0110 \\
(0.00519)\end{array}$ & - \\
\hline Age 69 & - & - & - & $\begin{array}{c}-0.0122 \\
(0.00512)\end{array}$ & - \\
\hline Age 70 & - & - & - & $\begin{array}{c}-0.0161 \\
(0.00492)\end{array}$ & - \\
\hline Age 71 & - & - & - & $\begin{array}{c}-0.0214 \\
(0.00414)\end{array}$ & - \\
\hline Age 72 & - & - & - & $\begin{array}{c}-0.0155 \\
(0.00604)\end{array}$ & - \\
\hline Age 73 & - & - & - & $\begin{array}{c}-0.0168 \\
(0.00587)\end{array}$ & - \\
\hline Age 74 & - & - & - & $\begin{array}{l}-0.0165 \\
(0.0077)\end{array}$ & - \\
\hline Age 75 & - & - & - & $\begin{array}{c}-0.0262 \\
(0.00478)\end{array}$ & - \\
\hline Age 76 & - & - & -- & $\begin{array}{r}-0.0120 \\
(0.0132)\end{array}$ & - \\
\hline Age 77 & - & - & - & $\begin{array}{l}-0.0120 \\
(0.0128)\end{array}$ & - \\
\hline
\end{tabular}


Figure 1A: Pension Wealth Accrual for Plan 67 Employees

Male born in 1950 commencing employment in 1980 at $\$ 40,000$ starting salary real discount rate: $3 \%$, inflation: $2.5 \%$, real wage growth: $1.1 \%$

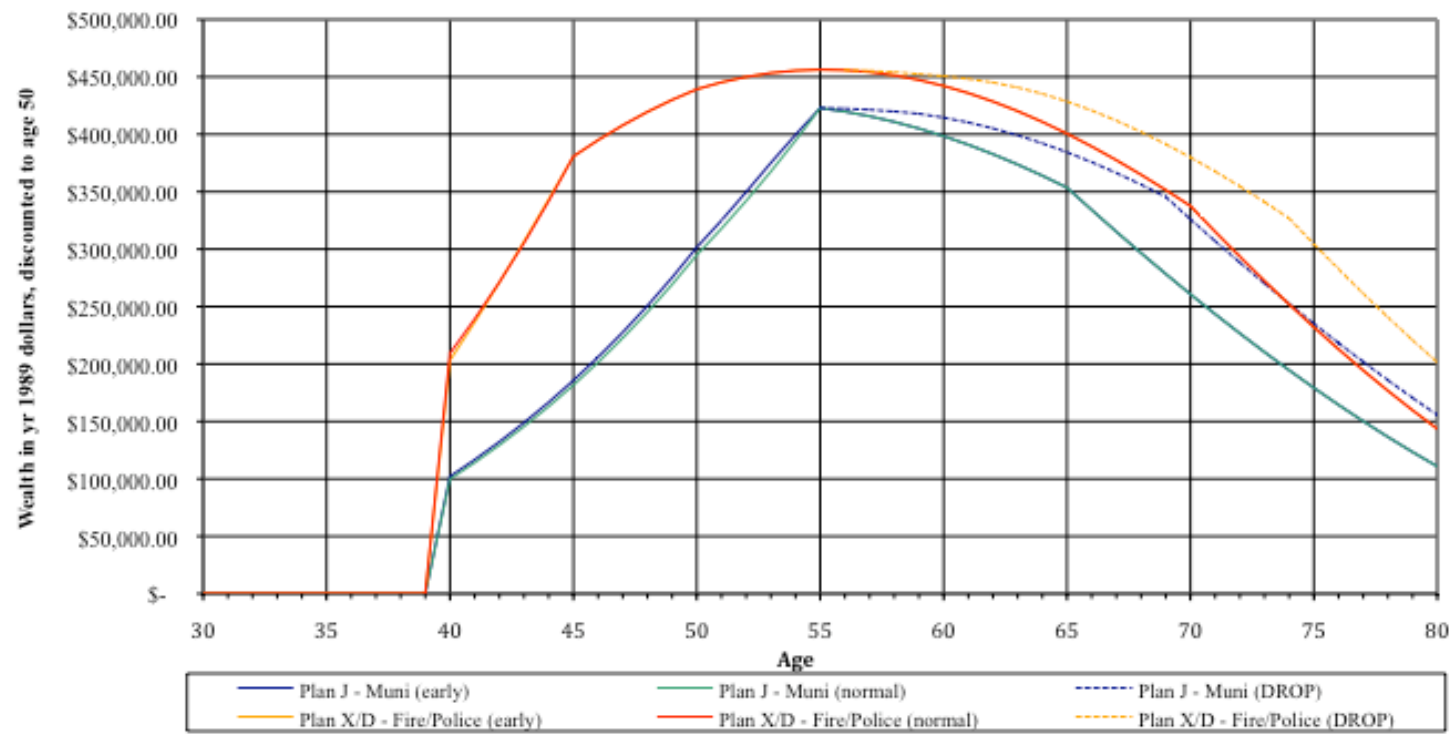

Figure 1B: Pension Wealth Accrual for Plan 67 Employees

Male born in 1950, commencing employment at ages 26, 28, 36 for Fire, Police and Municipal, respectively at \$40,000 starting salary, real discount rate: $3 \%$, inflation: $2.5 \%$, real wage growth: $1.1 \%$

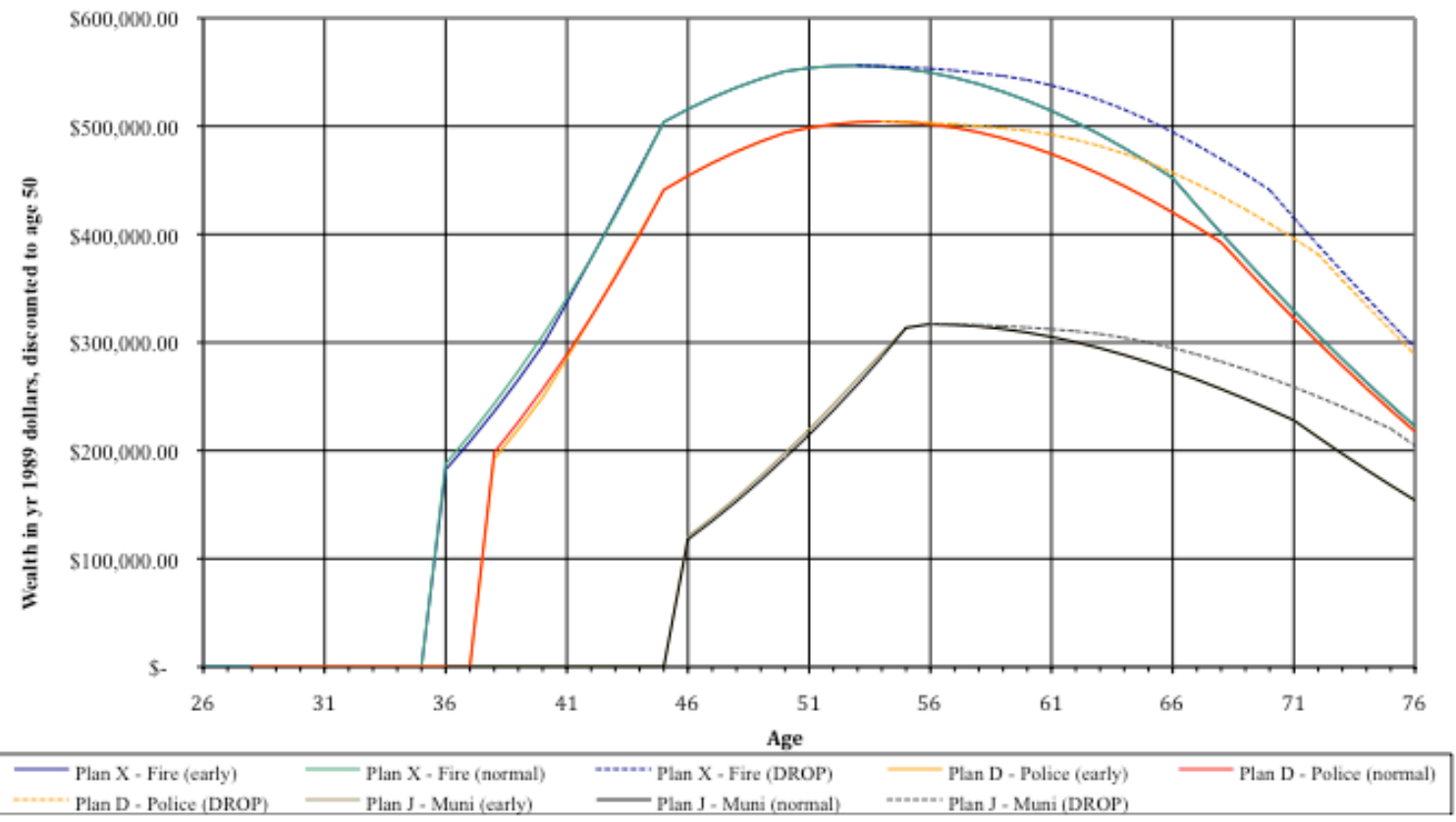




\section{RECENT WORKING PAPERS FROM THE CENTER FOR RETIREMENT RESEARCH AT BOSTON COLLEGE}

Housing Consumption in Late Life: The Role of Income, Health Shocks, and Marital Shocks Douglas A. Wolf and Janet M. Wilmoth, September 2010

Adjusting Social Security for Increasing Life Expectancy: Effects on Progressivity Courtney Monk, John A. Turner, and Natalia A. Zhivan, August 2010

Work and Retirement Patterns for the G.I. Generation, Silent Generation, and Early Boomers: Thirty Years of Change

Richard W. Johnson, Barbara A. Butrica, and Corina Mommaerts, July 2010

Spousal Health Shocks and the Timing of the Retirement Decision in the Face of ForwardLooking Financial Incentives

Courtney Harold Van Houtven and Norma B. Coe, June 2010

Incorporating Employee Heterogenity Into Default Rules for Retirement Plan Selection Gopi Shah Godi and Colleen Flaherty Manchester, May 2010

Accurately Measuring Health Over the Life Course

Fabian Lange and Doug McKee, May 2010

Getting to the Top of Mind: How Reminders Increase Saving

Dean Karlan, Margaret McConnell, Sendhil Mullainathan, and Jonathan Zinman, April 2010

The Shrinking Tax Preference for Pension Savings: An Analysis of Income Tax Changes, 1985-2007

Gary Burtless and Eric Toder, March 2010

Social Security, Benefit Claiming and Labor Force Participation: A Quantitative General Equilibrium Approach

Selahattin İmrohoroğlu and Sagiri Kitao, March 2010

How Much Is Enough? The Distribution of Lifetime Health Care Costs

Anthony Webb and Natalia Zhivan, February 2010

Impact of Immigration on the Distribution of American Well-Being

Gary Burtless, December 2009

Actual and Anticipated Inheritance Receipts

Norma B. Coe and Anthony Webb, December 2009

Will Automatic Enrollment Reduce Employer Contributions to 401(k) Plans Mauricio Soto and Barbara A. Butrica, December 2009

All working papers are available on the Center for Retirement Research website (http://crr.bc.edu) and can be requested bye-mail (crr@bc.edu)or phone (617-552-1762). 